\title{
Heavy metals stress, mechanism and remediation techniques in rice (Oryza sativa L.): A review
}

\author{
Sana Javaid ${ }^{1}$, Qamar uz Zaman ${ }^{1 *}$, Khawar Sultan ${ }^{1}$, Umair Riaz ${ }^{2}$, \\ Ambreen Aslam ${ }^{1}$, Saba Sharif ${ }^{1}$, Nusrat Ehsan ${ }^{1}$, Sajida Aslam ${ }^{3}$, Asma \\ $\mathrm{Jamil}^{4}$ and Shumaila Ibraheem ${ }^{5}$ \\ 1. Department of Environmental Sciences, The University of Lahore-Lahore-Pakistan \\ 2. Soil and Water Testing Laboratory for Research, Bahawalpur-63100-Pakistan \\ 3. Department of Chemistry, The University of Lahore-Lahore-Pakistan \\ 4. Department of Chemistry, University of Agriculture, Faisalabad-Pakistan \\ 5. College of Chemistry and Chemical Engineering Chongqing University, Chongqing 400044-China \\ *Corresponding author's email:qamar.zaman1@envs.uol.edu.pk \\ Citation \\ Sana Javaid, Qamar uz Zaman, Khawar Sultan, Umair Riaz, Ambreen Aslam, Saba Sharif, Nusrat Ehsan, Sajida \\ Aslam, Asma Jamil and Shumaila Ibraheem. Heavy metals stress, mechanism and remediation techniques in rice \\ (Oryza sativa L.): A review. Pure and Applied Biology. Vol. 9, Issue 1, pp403-426. \\ http://dx.doi.org/10.19045/bspab.2020.90045
}

Received: 08/08/2019 Revised: 25/10/2019 Accepted: 05/11/2019

Online First: 14/11/2019

\section{Abstract}

The rapid pace of urbanization and industrialization makes soil and environment polluted, which may cause a severe issue of food chain contamination. Discharge of heavy metal(oid)s from industrial and municipal wastewater streams, and groundwater contamination causes a reduction in crop yields, degradation of soils and ruin quality. Cultivated Asian rice and heavy metal(oid)s have two ways of interaction, either heavy metal(oid)s accumulation cause harmful effects on rice crop or rice plants possess their resistance mechanism to protect against the toxic effects of heavy metal(oid)s, their uptake, and translocation also detoxify the heavy metal(oids) contamination. Besides, several inorganic (liming and silicon) and organic (compost and biochar) amendments have been applied in the soils to reduce/immobilize heavy metal(oid)s stress in rice. Selection/development of rice varieties resistant to heavy metals stress and bioaccumulation, crop rotation, water management and exogenous application of microbes could be a reasonable approach to alleviate heavy metal(oid)s toxicity in rice. This article review that heavy metals, such as aluminum, arsenic, cadmium, chromium, copper, mercury, and lead are the major environmental pollutants, mainly in the places having more significant anthropogenic pressure. In agricultural areas, accumulation of heavy metals is of primary concern because of their adverse effects. This review article also briefly discusses the impact of the heavy metals on human health, soil, plants, and their metabolic mechanisms induced by the biological and geological redistribution of heavy metals by soil and water pollution.

Keywords: Accumulation; Dynamics; Heavy Metal(oids); Rice; Soil; Uptake

\section{Introduction}

Although there is plenty of food in the world produced to feed everybody, yet until now, 815 million people are hungry or living in extreme poverty. As presented in SDG 2 (Sustainable Development Goal 2), the world population is increasing, and it is expected to rise 10 billion in 2050. Hence the biggest challenge is to 
ensure the provision of enough food according to the nutritional needs. There is a need to increase food production approximately up to $50 \%$ globally because these increased 2 billion people have to feed by 2050 . Therefore, food security is a serious issue which needs a holistic approach to overcome all types of malnutrition, the sensible use of genetic resources and biodiversity, the income and productivity of minute level food producers and flexible change in food production patterns [1]. In 2016, the number of malnourished people worldwide was approximately 815 million, which is up from around 777 million in 2015 but significantly less from 900 million in the year 2000. This latest boost is the reason for immense concern and poses a serious challenge for global commitments to end the huger until 2030 [2]. The significant decline in rice production is due to various factors, including biotic, urbanization, and environmental. According to an estimate, there would be a drastic increase up to 9 billion in the world population by 2050 . This situation warns us to perk up the production of rice by using conventional techniques as well as the modern approaches of biotechnology so that we can compete with the needs of the population [3]. The influence of heavy metals on the development and growth of rice varies according to the specific heavy metal for that mechanism. Essential heavy metals such as $\mathrm{Cu}$, $\mathrm{Fe}$, and $\mathrm{Zn}$ play a useful role in the growth and development of rice. These heavy metals improve several essential mechanisms for the plant growth and enhanced yield and also the nutritional level of rice at their optimum level. Heavy metals such as $\mathrm{As}, \mathrm{Cd}, \mathrm{Hg}$ and $\mathrm{Pb}$ which do not play any valuable role in the growth of plant, severe impacts have been observed at very less concentrations of these heavy metals in growth medium. The review of published research work indicated that the presence of heavy metal(oid)s caused adverse effects in living organisms. Therefore, clean soil is needed to grow healthy rice plants which can be achieved by using low cost and less time taking techniques such as dilution and turnover of surface contaminated soil and addition of minerals, fertilizers or biochar. This review specifically concentrates on the nature, sources, properties with possible remediation strategies of heavy metals which can affect the nutritional value of rice and can ultimately disturb the food chain.

\section{Rice crop in the world}

Rice is one of the significant crops of the world because of its role as food content for humans and animals and also as raw material for different industries [4]. It is estimated that about fifty percent population of the world consume rice daily as dietary intake. Several industries also use various by-products of rice crop as raw material. Among other uses, rice straw is also used as animal feed and as organic manure in the soil [5]. Rice is ranked as the second most consumed food by humans. Humans take cereal food in their daily intake, and wheat bread and other derived meals are at the topmost priority. In 2016, rice was produced globally, about 483.1 million tons and consumed by over fifty percent of the population [6].

In the world, the demand for the food is increasing constantly, but the resources are decreasing simultaneously [7]. Rice is the foremost food crop yielded and consumed globally, accounting for almost $20 \%$ in cereals trade and approximately $26 \%$ in cereal yield [8]. The rice cultivated in Asia can be divided into different groups based on ecology, genetics, and different culinary properties. Different rice genetics (Indica Kato, Jaonica Kato, and aus) differ with the temperate and tropical regions. Aromatic rice with definite flavors are popular in Pakistan (Basmati), Iran (Sadri) and India. Rice of this region is known as drought tolerant and consists of early maturing type [9].

\section{Rice crop in Pakistan}

Currently, the main production of rice is produced in India, Vietnam, Japan, Pakistan, China, Bangladesh, Thailand, Philippines, Myanmar, and Indonesia. From the total production of rice, $92 \%$ is produced in Asian countries. Pakistan produces a significant amount of rice crop and is designated as the fourth largest country after China, India, and 
Indonesia [10]. In Pakistan, Punjab province is the largest rice-producing region of the country. In 2015-16, rice crop covered 4.45 million acres of the total land and 3.502 million tones was the total production of rice. Sindh province contributes $38 \%$ of the national production of rice crop while KPK and Balochistan provinces contribute $2 \%$ and $8 \%$, respectively.

On the other hand, Punjab province contributes up to $52 \%$ of the national rice production [11]. After wheat, rice is the second staple food and foremost resource of foreign exchange income after cotton and accounts for $0.6 \%$ of Pakistani GDP and $3 \%$ in value-added for agriculture zone. Rice was cultivated on 2.724 million hectares during 2016 in Pakistan, which was $0.6 \%$ less than the previous year's cultivation area of 2.792 million hectares. However, there was an increase in the production of rice up to $0.7 \%$. The reasons for the decrease in cultivation area were shifting of rice crop to maize and sugarcane crop by farmers and less domestic prices of the crop in the market [11]. In Punjab, rice was being cultivated on an area of 1.736 million hectares with $2.5 \%$ decrease over the previous year, mainly due to the low market prices. While 3.475 million tons of production with a $10.8 \%$ increase in Basmati production was achieved that accounts for $51 \%$ of the total national production of rice in Pakistan. The yield remained better due to adequate supply/availability of inputs at subsidized electricity rates and intermittent rains at appropriate intervals [12]. Three types of rice varieties are cultivated in Pakistan, i.e., Basmati types (aromatic), medium-long grain, and bold grain. Basmati rice is popular throughout the world for its excellent cooking and eating qualities combined with a very pleasant aroma. Super Basmati, an aromatic rice variety, was released in 1996 about2 decades ago and is still the most popular among consumers, traders and farmers. In 2001 and 2011, two different varieties of Basmati rice, named "Basmati 2000" and "Basmati 515", respectively, were introduced in Pakistan but none of them completely substituted or competed in the field against "Super Basmati" variety [13].

\section{Major constraints in rice production}

The hindrances are generally categorized into socio-economic issues, technological, biophysical, soil fertility, agricultural equipment, and institutional management. Some major constraints faced by the farmers in the production of rice crop were disease and pest's incidence $(80 \%)$, lack of market or crop price $(75 \%)$, shortage of labor $(65 \%)$ and heavy metal(oid)s stress and salinity (36\%) problems. Good management practices of diseases, pests, and soil salinity issues will help to enhance the production quantity in all rice cultivated areas [14].

\section{Nature of heavy metal(oid)s}

Heavy metal(oid)s are the natural substances that cannot be destroyed or degraded biologically. Life cannot survive and develop without the metallic ions as the life is as much organic as inorganic. A heavy metal(oid) is poisonous when comparatively it is dense metalloid or metal which is well-known for its possible toxicity, especially in the context of the soil environment. Excess of necessary concentration of heavy metals or unwanted quantity on earth crust is termed as the toxicity of heavy metals (Figure 1). These heavy metals increase by anthropogenic activities and enter in the human, animal and plant tissues through inhalation, manual handling, and diet, and can also bind to, and interrupt the working of essential cellular mechanisms. Heavy metal(oid)s can be major environmental pollutants; their potential toxicity is a problem of rising significance for nutritional, environmental, evolutionary, and ecological reasons. The heavy metal(oid)s in the soil are not biodegradable and therefore, are enormously persistent in the environment [15]. Essential heavy metal(oid)s

Several heavy metal(oid)s ( $\mathrm{Zn}, \mathrm{Fe}$, and $\mathrm{Cu}$ ) are essential for animals and plants [16]. The availability in a specific amount, metal(oid)s such as $\mathrm{Co}, \mathrm{Ni}, \mathrm{Zn}, \mathrm{Mn}, \mathrm{Fe}, \mathrm{Mo}$, and $\mathrm{Cu}$ are some essential micronutrients [17]. The uptake of these essential micronutrients in excess to plant needs can show toxic outcomes [18]. 


\section{Source of heavy metal(oid)s}

In the environment, there are various sources of heavy metal(oid)s such as domestic sewage, agricultural sources, industrial sources, atmospheric sources, and natural sources (Figure 2) $[8,19]$. In the developing world, the terrestrial environment is being contaminated by a variety of sources including smelting and mining processes, electroplating, excess fertilization, wastewater irrigation, and sewage sludge [20], and all of these activities may result in agricultural loam pollution by heavy metal(oid)s $[21,22]$ (Figures $1 \& 2$ ). In the plant systems, different metal(oid)s have wide ranges of sources as described in (Table 1).

\section{Effects of heavy metal(oid)s on plants}

Heavy metal(oid)s have negative effects on the biochemical and physiological function of plants. The majority of these apparent effects are chlorosis, leaf rolling altered metabolism, efflux of cations, necrosis, inhibition in growth rate, altered stomatal actions, alteration in membrane mechanisms, decreased potential of water, change in various essential enzymes, inhibition of photosynthesis and inhibition of respiration process [23]. All of the plant species and human beings are affected by the heavy metal(oid)s stress. A short comparison of heavy metal(oid)s stress on the rice growth, and human beings are described in (Table $2 \& 3$ ).

Remediation potential of heavy metal(oid)s

It is widely accepted that metal toxicity depends on the metal's bioavailability in soil and the relative concentrations of other compounds, which usually moderate the toxicity responses [24]. Some heavy metal(oids) their concentration in soil at different sites are mentioned in (Table 4). Various remediation techniques are used to reduce potentially toxic metal(oid)s bioavailability for plant uptake some of them are: liming with different compounds such as slag $\left(\mathrm{CaSiO}_{3}\right)$, slaked lime $\left(\mathrm{Ca}(\mathrm{OH})_{2}\right)$, burnt lime $(\mathrm{CaO})$, limestone $\left(\mathrm{CaCO}_{3}\right)$ and dolomite $\left(\mathrm{CaMg}\left(\mathrm{CO}_{3}\right)_{2}\right)$. Use of some organic amendments, water management, $\mathrm{Zn}$ fertilization, and crop rotation have also been found to be effective in the reduction of metal uptake by the plants (Figure 3) [25].

Dynamics of various heavy metal(oid)s in the soil-plant systems

Arsenic (As)

Nature of Arsenic

Arsenic (As) is highly toxic and class I carcinogen as classified by U.S. EPA, Environmental Protection Agency of the United States, and can cause serious risk to the human health [26]. Arsenic occurs in nature in the form of major constituents as arsenate, arsenides, elemental As, oxides, sulfides, and other almost 200 minerals [27, 28]. Arsenic is the main component of naturally occurring sulfur-rich minerals in the geological environment such as orpiment $\left(\mathrm{A}_{2} \mathrm{~S}_{3}\right)$, arsenopyrite ( $\mathrm{FeAsS})$ and realgar $\left(\mathrm{As}_{4} \mathrm{~S}_{4}\right)$.

\section{Sources of arsenic}

Many natural processes like alluvial deposits and weathering of rocks can release As into paddy environment and contribute to increasing the amount of As. On the other hand, various anthropogenic activities such as the use of As rich water in the irrigation system and mining activities enhance the deposition of As in the paddy ecosystems. Arsenic containing wood preservatives, herbicides, and insecticides are some other anthropogenic sources which affect rice ecosystem [29].

Uptake and translocation mechanism of arsenic

In paddy ecosystem, arsM gene coded process can convert inorganic As into organic As such as MMA(III), MMA(V), DMA(III) and $\operatorname{DMA}(\mathrm{V})$ which are mono-methyl-arsonous and dimethylarsinous respectively [30]. Organic As species that are MMA (V) and DMA (V)in rice crop can enter from rhizosphere where microorganisms act and mediate methylation process because rice plants cannot methylate inorganic Asin-vivo [26]. There is not any specific mechanism which can show the uptake of As in rice crop. But it is known that a gene, aquaporin Lsil, can mediate the uptake of organic As in the rice crop [31]. 


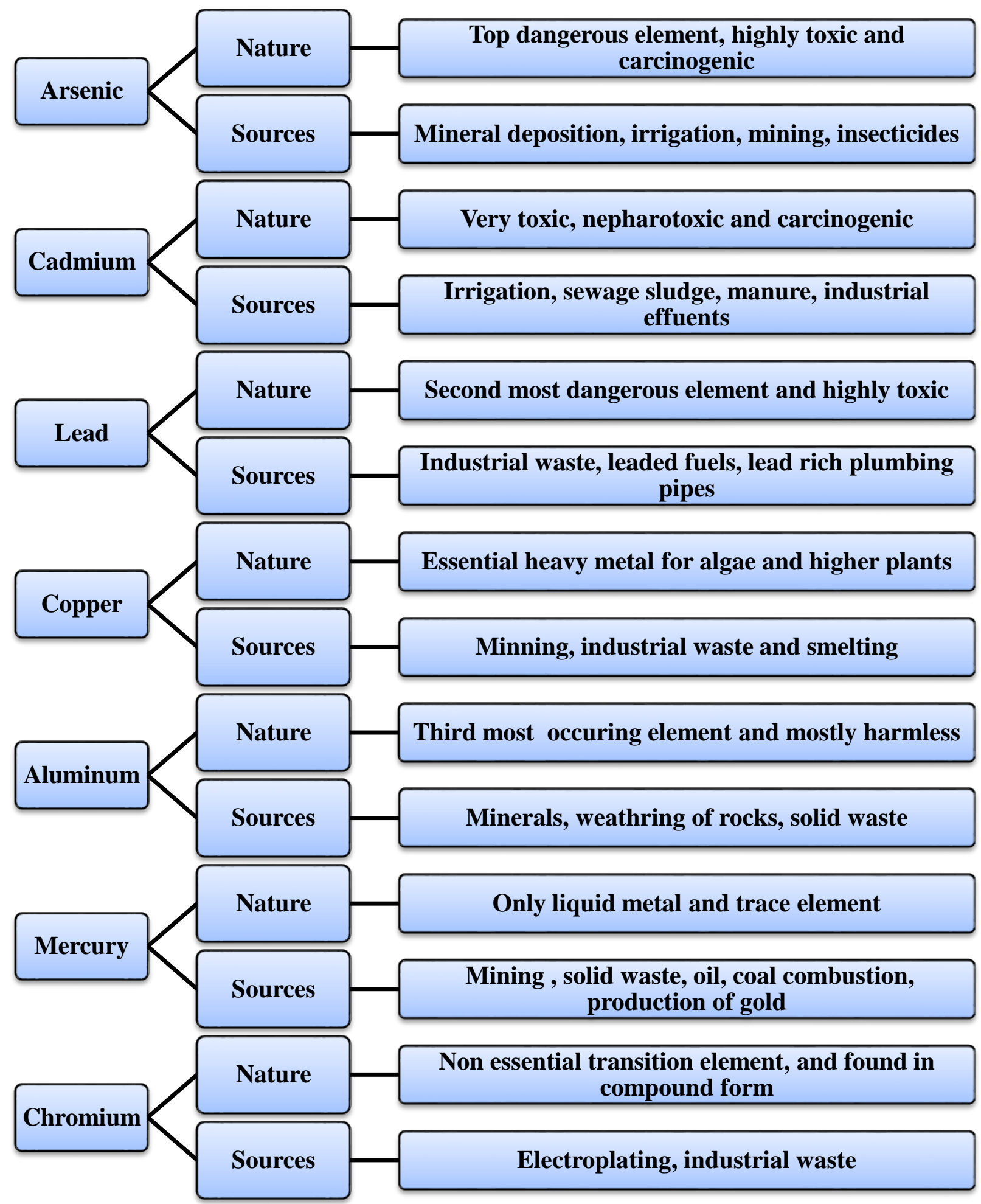

Figure 1. Nature and Sources of Heavy Metal(oids) 
Javaid et al.

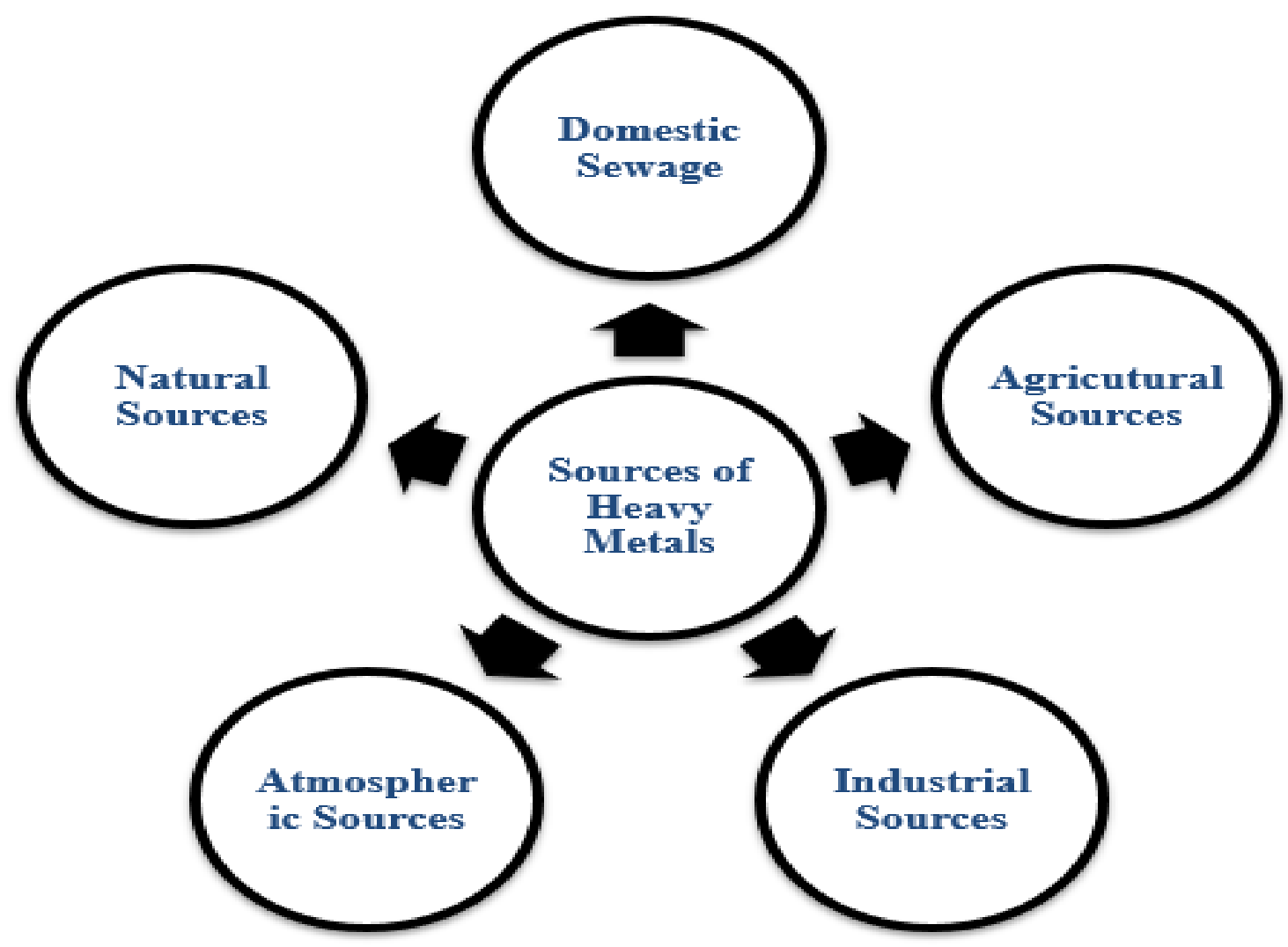

Figure 2. Sources of heavy metal(oid)s

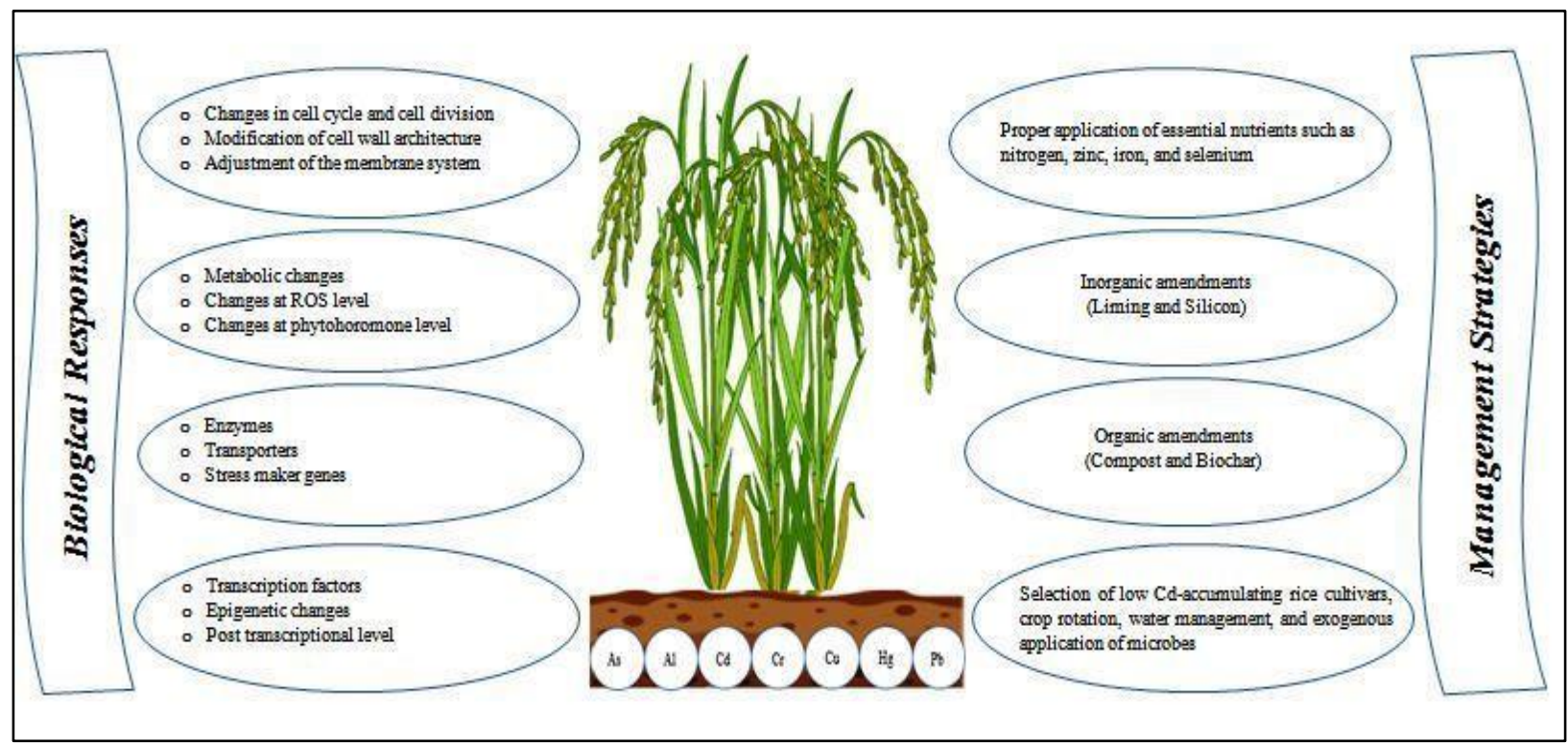

Figure 3. Remediation techniques and management strategies 
Table 1. Ranges of heavy metal(oid)s in plant

\begin{tabular}{|c|c|c|}
\hline Sr. No. & Heavy metal(oid)s & Range $\boldsymbol{\mu g} / \mathbf{g}$ dry weight on land plants [55] \\
\hline 1 & $\mathrm{As}$ & $0.02-7.0$ \\
\hline 2 & $\mathrm{Cd}$ & $0.10-2.40$ \\
\hline 3 & $\mathrm{Hg}$ & $0.005-0.02$ \\
\hline 4 & $\mathrm{~Pb}$ & $1-13$ \\
\hline 5 & $\mathrm{Sb}$ & $0.02-0.06$ \\
\hline 6 & $\mathrm{Co}$ & $0.05-0.5$ \\
\hline 7 & $\mathrm{Cr}$ & $0.2-1$ \\
\hline 8 & $\mathrm{Cu}$ & $4-15$ \\
\hline 9 & $\mathrm{Fe}$ & 140 \\
\hline 10 & $\mathrm{Mn}$ & $15-100$ \\
\hline 11 & $\mathrm{Mo}$ & $1-10$ \\
\hline 12 & $\mathrm{Ni}$ & 1 \\
\hline 13 & $\mathrm{Sr}$ & 0.30 \\
\hline 14 & $\mathrm{Zn}$ & $8-100$ \\
\hline
\end{tabular}

Table 2. Effects of heavy metal(oid)s accumulation on rice crop

\begin{tabular}{|c|c|c|}
\hline Heavy metal(oid)s & Effect on rice crop & References \\
\hline$x^{2}$ & $\begin{array}{l}\text { Reduces plant height, shoot biomass, grain and straw yield reduction, } \\
\text { straight head disease }\end{array}$ & {$[66,67]$} \\
\hline $\mathrm{Pb}$ & $\begin{array}{l}\text { Inhibition in seed germination, fresh and dry biomass, leaf area, } \\
\text { chlorophyll and growth }\end{array}$ & [68] \\
\hline $\mathrm{Cu}$ & $\begin{array}{l}\text { Decrease in seed germination, repressive impression in plant growth and } \\
\text { reduction in root and shoot length }\end{array}$ & [69] \\
\hline $\mathrm{Cd}$ & Inhibit oxidative reactions and nitrogen metabolism & [70] \\
\hline $\mathrm{Al}$ & $\begin{array}{l}\text { Reduction of root development, reduce plant vigor, inhibits shoot } \\
\text { escalation, reduce yield }\end{array}$ & [71] \\
\hline $\mathrm{Hg}$ & $\begin{array}{c}\text { Decreases plant height, reduces tiller, reduce panicle formation, yield } \\
\text { reduction }\end{array}$ & [55] \\
\hline $\mathrm{Cr}$ & $\begin{array}{l}\text { Reduction of root development, decrease in grain weight, decrease in } \\
\text { yield }\end{array}$ & [57] \\
\hline
\end{tabular}

\section{Table 3. Effects of heavy metals accumulation on human health}

\begin{tabular}{|c|c|c|}
\hline Heavy metal(oid)s & Effect on human beings & References \\
\hline $\mathrm{As}$ & $\begin{array}{c}\text { Skin Hyperkeratosis, kidney disease, heart diseases, respiratory } \\
\text { complications, gall bladder cancer, ung cancer, bronchitis, dermatitis, } \\
\text { poisoning }\end{array}$ & {$[72-75]$} \\
\hline $\mathrm{Pb}$ & $\begin{array}{c}\text { Developmental delay, congenital paralysis mental retardation in kids, fatal } \\
\text { infant encephalopathy, sensor neural deafness, gastrointestinal damage, } \\
\text { epileptics, acute and then chronic harm to CNS, Liver dysfunction and } \\
\text { kidney failure. }\end{array}$ & {$[75]$} \\
\hline $\mathrm{Cu}$ & $\begin{array}{c}\text { Liver damage, kidney dysfunction, intestinal and stomach irritation and } \\
\text { anemia }\end{array}$ & {$[75]$} \\
\hline $\mathrm{Cd}$ & $\begin{array}{c}\text { Lung disease, renal dysfunction, Lung cancer, bone marrow cancer, Bone } \\
\text { defects (Osteoporosis, Osteomalacia), gastrointestinal disorder, bronchitis, } \\
\text { increased blood pressure and kidney damage }\end{array}$ & {$[39]$} \\
\hline $\mathrm{Al}$ & Kidney Failure & {$[71]$} \\
\hline $\mathrm{Hg}$ & Brain damage, Kidney dysfunction and Lung damage & {$[76]$} \\
\hline $\mathrm{Cr}$ & DNA damage, Alterations in transcription and replication of DNA & {$[77]$} \\
\hline
\end{tabular}


Table 4. An overview of heavy metal(oids) concentration in soil at various sites

\begin{tabular}{|c|c|c|c|c|c|}
\hline Heavy metal(oids) & $\begin{array}{c}\text { Concentration in soil } \\
\mathrm{mg} / \mathrm{kg}\end{array}$ & $\begin{array}{c}\text { Maximum Permissible } \\
\text { Limit* }\end{array}$ & $\begin{array}{c}\text { Fold higher than Permissible } \\
\text { Limit }\end{array}$ & Study Area & References \\
\hline As & $\begin{array}{c}64 \\
131 \\
354 \\
4357 \\
7490\end{array}$ & ( & $\begin{array}{c}3.2 \\
6.6 \\
17.7 \\
217.9 \\
374.5\end{array}$ & $\begin{array}{l}\text { Bolivia } \\
\text { Korea } \\
\text { China } \\
\text { Italy } \\
\text { Spain }\end{array}$ & $\begin{array}{l}{[78]} \\
{[79]} \\
{[80]} \\
{[81]} \\
{[82]}\end{array}$ \\
\hline $\mathrm{Cd}$ & $\begin{array}{l}14 \\
14 \\
16 \\
19 \\
42 \\
\end{array}$ & 3 & $\begin{array}{c}4.6 \\
4.7 \\
5.4 \\
6.4 \\
14.0 \\
\end{array}$ & $\begin{array}{c}\text { China } \\
\text { Mexico } \\
\text { Switzerland } \\
\text { India } \\
\text { South Italy } \\
\end{array}$ & $\begin{array}{l}{[83]} \\
{[84]} \\
{[85]} \\
{[86]} \\
{[87]}\end{array}$ \\
\hline $\mathrm{Cr}$ & $\begin{array}{c}224 \\
418 \\
590 \\
4309 \\
\end{array}$ & 100 & $\begin{array}{c}2.2 \\
4.2 \\
5.9 \\
43.1\end{array}$ & $\begin{array}{l}\text { Germany } \\
\text { Greece } \\
\text { China } \\
\text { Spain }\end{array}$ & $\begin{array}{l}{[88]} \\
{[89]} \\
{[90]} \\
{[91]}\end{array}$ \\
\hline $\mathrm{Cu}$ & $\begin{array}{c}235 \\
448 \\
19581 \\
35582 \\
\end{array}$ & 100 & $\begin{array}{c}2.4 \\
4.5 \\
195.8 \\
355.8 \\
\end{array}$ & $\begin{array}{l}\text { Portugal } \\
\text { China } \\
\text { Australia } \\
\text { Mexico }\end{array}$ & $\begin{array}{l}{[92]} \\
{[93]} \\
{[94]} \\
{[84]}\end{array}$ \\
\hline $\mathrm{Ni}$ & $\begin{array}{c}153 \\
200 \\
201 \\
373 \\
2603 \\
\end{array}$ & 50 & $\begin{array}{c}3.1 \\
4.0 \\
4.0 \\
7.5 \\
52.1 \\
\end{array}$ & $\begin{array}{c}\text { China } \\
\text { Turkey } \\
\text { Zimbabwe } \\
\text { Spain } \\
\text { Mexico } \\
\end{array}$ & $\begin{array}{l}{[93]} \\
{[95]} \\
{[96]} \\
{[91]} \\
{[84]} \\
\end{array}$ \\
\hline $\mathrm{Pb}$ & $\begin{array}{c}302 \\
452 \\
711 \\
1988 \\
4500 \\
\end{array}$ & 100 & $\begin{array}{c}3.0 \\
4.5 \\
7.1 \\
19.9 \\
45.0 \\
\end{array}$ & $\begin{array}{l}\text { Brazil } \\
\text { Uganda } \\
\text { UK } \\
\text { China } \\
\text { China } \\
\end{array}$ & $\begin{array}{c}{[97]} \\
{[98]} \\
{[99]} \\
{[100]} \\
{[101]}\end{array}$ \\
\hline $\mathrm{Zn}$ & $\begin{array}{c}393 \\
905 \\
1168 \\
370 \\
3833 \\
\end{array}$ & 300 & $\begin{array}{c}1.3 \\
3.0 \\
3.9 \\
1.2 \\
12.8 \\
\end{array}$ & $\begin{array}{c}\text { Portugal } \\
\text { Portugal } \\
\text { Germany } \\
\text { Nigeria } \\
\text { China }\end{array}$ & $\begin{array}{c}{[102]} \\
{[92]} \\
{[88]} \\
{[103]} \\
{[100]}\end{array}$ \\
\hline
\end{tabular}




\section{Effects of as on rice}

Arsenic is a non-essential harmful metalloid of which the high level in rice grains is a severe problem both in terms of rice production and quality and in terms of human health.

Arsenic-rich groundwater is used extensively, mostly in the dry season, for irrigation of rice plants in India, Pakistan, and Bangladesh [32]. The natural concentration of As in paddy soils ranges from 4 to $8 \mathrm{mg} \mathrm{kg}^{-1}$, which may rise by up to $83 \mathrm{mg} \mathrm{kg}^{-1}$ as reported in many parts of the world where As-contaminated groundwater is applied for irrigation of paddy soils. South Asian countries with high As in their groundwater include Nepal, various parts of India, Pakistan, Bangladesh, Myanmar, Vietnam, Cambodia, China, Taiwan, and various regions of Sumatra in Indonesia [33, 34 ]. Due to the presence of high As contents in paddy soils originating from As-contaminated irrigation water, the rice accumulates comparatively higher levels of As (20-22 times greater) than other staple crops [35]. Arsenic levels and its chemical species vary significantly based on the variety of rice used and the local geology of the area. Inorganic arsenicals predominate over the organic As forms in both cooked and uncooked rice and the intake of As via rice into the human body relies on the variety of rice and the process of cooking used [36-38]. Hua et al. [3] explained that the accumulation of As in rice have a serious human health threats and also the marketability of products. Paddy rice accumulates As from the irrigation water and soil, and the intake of this As rich rice acts as the exposure means to the humans on any stage of the life. As also has a negative impact on the quality, yield, and the growth of rice. Identification of poisoning of millions of inhabitants of India, China, West Bengal, and Bangladesh, has taken to a significant advancement in the perceptive of As exposure pathways, bioactivity, toxicity levels in the water-soil-plant system and mechanism of the bioaccumulation patterns. A comprehensive study of heavy metal(oids) stress on rice plant is presented in (Table 5).

\section{Cadmium (Cd)}

Nature of cadmium

Cadmium (Cd) is normally a non-essential nutrient which has nephrotoxic, carcinogenic and teratogenic effects on living beings. Cadmium is a very toxic heavy metal that may accumulate in the crops and then leads to the continuous toxicity disorders in human beings and livestock. In agricultural soil, the permissible limit of $\mathrm{Cd}$ is $100 \mathrm{mg} \mathrm{kg}^{-1}$ of soil [39].

\section{Sources of cadmium}

Some major sources of $\mathrm{Cd}$ are irrigation with $\mathrm{Cd}$ rich water, sewage sludge, industrial effluents, excessive use of contaminated fertilizers, and manure. These sources have contaminated the agricultural soil, which becomes a significant issue [39].

Uptake and translocation mechanism of $\mathrm{Cd}$ Cadmium is a non-essential nutrient for the growth of the plant. Therefore, no specific transporters for $\mathrm{Cd}$ are expected to be found in plants. Instead, other transporters for essential metal(oid)s such as $\mathrm{Zn}, \mathrm{Mn}$ and Fe may be responsible for the transport of $\mathrm{Cd}$ in plants. During the past few years, several transporters for $\mathrm{Cd}$ have been identified in rice plant [40]. The Nramps (Natural Resistance Associated Macrophage Proteins) compose a huge family which is conserved evolutionary throughout the organisms. These Nramps are concerned with the intercellular transport, detoxification, uptake and translocation of transition metal(oid)s. In the rice genome, there are seven Nramp. genes, two of which have been functionally characterized at the molecular and cellular level. OsNramp5 is identified to mediate $\mathrm{Cd}$ transport [41]. This conclusion was based on the findings that knockdown and knock out of OsNaramp5 result in an outstanding reduction of $\mathrm{Cd}$ and manganese uptake, signifying that the exact expression of OsNramp5 will be critical for $\mathrm{Cd}$ and Manganese uptake in to the roots [40].

\section{Effects of Cd on rice}

Cadmium stress reduces seed germination and rice growth. It also causes the necrosis and chlorosis. Cadmium toxicity reduces shoot and root length, root and leaf area, and the number 
of roots and leaves per plant. Furthermore, higher concentrations of $\mathrm{Cd}$ restrict gas exchange characteristics and photosynthesis in rice plants [42].

\section{Lead $(\mathbf{P b})$}

\section{Nature of lead}

Lead is one of the major inorganic contaminants which is used since ancient times. Its occurrence in atmosphere and soil is damaging for living organisms. In soil, it constitutes complexes with the elements of soil, interferes within the soil-plant and environment associations. It is novel in its solubility in the soil, behavior form, mobility, and bioavailability to ecosystem and plants [4]. Agency for Toxic Substances and Disease Registry (ASTDR, 2003) categorized the $\mathrm{Pb}$ as the second most dangerous element due to exposure potential, toxicity and occurrence, only after As lead is the most toxic substance having greater transfer rate from soil to the plants, Lead has been extensively studied for the purpose of quality, bio-testing, and safety of foods [43].

\section{Sources of $\mathbf{P b}$}

Lead accumulating and added up in the agricultural soil by various anthropogenic activities. Industrial wastes, leaded fuels, and $\mathrm{Pb}$ rich plumbing pipes are amongst the chief sources of $\mathrm{Pb}$ that are contaminating the agricultural soils [44].

\section{Uptake and translocation mechanism of $\mathbf{P b}$}

Uptake, translocation and the storage mechanism of various hazardous and toxic metal(oid)s in the plants is similar as for the acquisition of micronutrients from soil to the plants. Generally, rice plants acquire micronutrients by roots from the soil, and this mechanism is supported by soil organic matter, chelating agents (by solubilizing micronutrients in rhizosphere), soil $\mathrm{pH}$ and redox reactions. Lead uses the same mechanism to get absorbed in the plants [45]. Lead in $\mathrm{Pb}^{+2}$ ionic form in soil solution is absorbed by plant roots and can disturb mineral uptake by roots. This lead content is taken up by the translocating water flow in the roots of the rice plant. The young cells located at the root apices are mainly responsible for the $\mathrm{Pb}$ uptake because the adsorption of $\mathrm{Pb}$ is higher here instead of the complete root surface. It is observed that root apices have lowest rhizodermic $\mathrm{pH}$ creating acidic microenvironment hence increasing the solubility of $\mathrm{Pb}$ in soil. Lead might be taken up by the plants through various pathways, which include ionic channels, co transporters, antitransporters, and proton pumps [46].

\section{Effects of $\mathbf{P b}$ on rice}

Lead is the toxic metal which instead of participating in rice plant growth and development, severely disturbs the morphphysiological structures, crop growth, plant metabolism and crop productivity.

Lead reduces the growth and yield of rice plants by changing biochemical and physiological properties. Lead affects the plants at all the stages of growth, starting from germination to the maturity level. Accumulation of $\mathrm{Pb}$ affects the root ratio, seed germination, fresh weight, dry weight, and shoot ratio in the rice plants. These effects are more adverse when leading $\mathrm{Pb}^{+2}$ accumulated in higher concentration. Lead inhibits the growth and viability of rice seedlings and enhances the regulation of ROS (reactive oxygen species) production rate [4].

\section{Copper $(\mathbf{C u})$ \\ Nature of Copper}

Copper $(\mathrm{Cu})$ is the heavy metal which is essential for algae and higher plants, especially for the photosynthesis process. In photosystem -I of the plants, $\mathrm{Cu}$ is the main constituent of the primary electron donor. Because $\mathrm{Cu}$ can easily loss or gain an electron, it's the cofactor of monooxygenase, dioxygenase and oxidase (for example ammonia monoxidaze, lysyl oxidase, ceruloplasmin and amine oxidase) and other enzymes concerned with the removal of superoxide radicals, for example, ascorbate oxidase and superoxide dismutase [19].

\section{Sources of $\mathbf{C u}$}

Copper is an essential element for the metabolism and normal growth of living organisms. Copper is also an essential element for several proteins such as cytochrome oxidase of the respiratory ETC (electron transport chain) and plastocyanin of the photosynthetic system. Increased mining and industrial activities have raised the level of $\mathrm{Cu}$ 
in ecosystems. Some anthropogenic activities, including smelting and mining of $\mathrm{Cu}$ rich ores, add $\mathrm{Cu}$ to the environment. Mining activities produce a significant amount of tailings and waste rocks which are dumped at the surface [19].

\section{Effects of $\mathrm{Cu}$ on rice}

Copper is an important metal for rice growth and development. It is recognized as a plant micronutrient and plays a major role in ATP synthesis and $\mathrm{CO}_{2}$ assimilation. Exposure of rice to the higher concentrations of $\mathrm{Cu}$ significantly decreases the length of root and shoot. Rice plant that is induced with higher concentrations of $\mathrm{Cu}$ toxicity reduces their growth, which leads to the reduction of productivity and also impairs various important cellular processes such as electron transport and photosynthesis [47].

Uptake and translocation mechanism of $\mathrm{Cu}$ In soil, $\mathrm{Cu}$ is usually found in the bound forms to soil solids; hence, the amount of availability is very low. The $\mathrm{Cu}^{+2}$ ionic form is known as an available form while other species bound with the organic ligands or inorganic $\mathrm{OH}$ and $\left(\mathrm{CO}_{3}\right)_{2}$ depending on soil $\mathrm{pH}$. On the other hand, the speciation of $\mathrm{Cu}$ is not fully known. Copper chaperones and $\mathrm{Cu}$ dependent enzymes have the structural and functional detailed information. Copper toxicity in plants is due to the higher level of exposure, which needs to be overcome by controlling $\mathrm{Cu}$ uptake, its utilization, and detoxification through different means [48].

\section{Aluminum (Al)}

\section{Nature of Aluminum}

After the oxygen and silicon, third-most occurring element is aluminum (Al) that constitutes almost $7 \%$ of the total inorganic solid mass of earth crust (Frankowski, 2016). Soil Al either occurs in harmless structures such as aluminosilicates and precipitate or attached with the ligands [49].

\section{Sources of Al}

In nature, $\mathrm{Al}$ does not occur in free form but mostly found in rocks such as in igneous rocks in the form of aluminosilicates. Aluminum is present in water and various foods. Naturally, it enters into the environment through minerals and weathering of rocks. Aluminum also released in the environment through anthropogenic activities such as wastewater effluent, solid waste of Al-based industries, and air emissions. As $\mathrm{Al}$ is the major element of the earth crust, the natural weathering mechanisms mostly exceed the addition of releases to land air and water associated with the activities of human [50].

\section{Effects of Al on rice}

Despite numerous studies on rice high aluminum sensitivity, its exact pathways remain completely unknown. It is also unknown that how Al helps certain plants grow faster. In different areas of the world, the toxicity of $\mathrm{Al}$ is the growth limiting factor in acidic soil plants. Aluminum toxicity is not primarily identifiable in plants. Iron deficiency is induced in Sorghum, Wheat, and Rice when an excessive amount of aluminum is deposited. Also induce the deficiency of calcium and calcium transport problems such as the collapse of petioles or growing plants and rolling or curling of young leaves [49].

\section{Uptake and translocation mechanism of Al} In many crops, $\mathrm{Al}^{+3}$ is absorbed through roots located in apoplast. Cations such as highly charged $\mathrm{Al}^{+3}$ are attracted and bonded by the pectin present in cell walls and negative charges fixed on membrane surfaces. This is still unknown that which is more toxic for the plants among apoplastic $\mathrm{Al}^{+3}$ and entrance of $\mathrm{Al}^{+3}$ in the cytosol. Solute flow by apoplast can be restricted by binding the $\mathrm{Al}^{+3}$ in the cell walls to the pectin. It also rigidifies the walls [51]. Aluminum can directly inhibit the uptake of nutrients by blocking ion channels which are involved in $\mathrm{K}^{+}$and $\mathrm{Ca}^{2+}$ influx. Callose $(1,3$ beta D-glucan) production is induced in the apoplast by the accumulation of the higher amount of $\mathrm{Al}^{+3}$ which affects the functions of the membrane by binding with the proteins and lipids or displacing calcium from various critical locations on membranes [51].

\section{Mercury (Hg)}

\section{Nature of mercury}

Mercury $(\mathrm{Hg})$ is known as the only liquid metal found in many common products and processes that make use of its unique characteristics. $\mathrm{Hg}$, 
zinc, and Cd belong to the same group of the periodic table. $\mathrm{Hg}$, at the $\mathrm{STP}$, is only liquid metal having atomic number80 and atomic weight 200. It's melting point is $-13.6^{\circ} \mathrm{C}$, density is $13.6 \mathrm{~g} / \mathrm{cm}^{3}$, and the boiling point is $357^{\circ} \mathrm{C}$. $\mathrm{Hg}$ is normally obtained as the byproduct of various ore processing protocols [52].

\section{Sources of $\mathbf{H g}$}

Mercury is naturally found element, but it is directly mobilized by the human beings for thousands of years into terrestrial and aquatic ecosystems by mining, its use in electronics devices, paints and other products, by extracting precious metal(oid)s through $\mathrm{Hg}$, presence as trace element in metal ores, coals and many other materials and through industries like chlor-alkai plants (used as catalysts) [53]. Solid waste incinerations, as the medical and municipal waste, Oil and coal combustion, production of gold and pyro metallurgical processes are some other sources of $\mathrm{Hg}$ contamination [54].

\section{Effects of $\mathrm{Hg}$ on rice}

Mercury is a non-essential element for the growth of rice. Agricultural soil is contaminated by the addition of $\mathrm{Hg}$ through lime, manures, sludge, and fertilizers. The dynamics are not linear between the quantity of $\mathrm{Hg}$ which occurs in the agricultural soil and the uptake of $\mathrm{Hg}$ by plants and it depend on various variables such as soil $\mathrm{pH}$, plant species, cation exchange ratio, and soil aeration. When $\mathrm{Hg}$ accumulates in the excess in rice plants, it reduces tiller, decreases plant growth, reduces panicle formation, reduces crop yield, and enhances the bioaccumulation in seedling, root, and shoot [55].

Uptake and translocation mechanism of $\mathbf{H g}$

The atmosphere is leading pathway of transporting $\mathrm{Hg}$ emissions, while ocean and land processes take part in the $\mathrm{Hg}$ redistribution in freshwater, marine and terrestrial ecosystems and manufacturing of $\mathrm{CH}_{3} \mathrm{Hg}$ which derives the foremost route of human exposure, consumption of fish, especially marine fish. The spatial and temporal scales of $\mathrm{Hg}$ transport in the atmosphere and its transport to the terrestrial and aquatic ecosystems based on its physical and chemical forms. Following the emissions, the elemental $\mathrm{Hg}[\mathrm{Hg}(0)]$ could be transferred to the long distances before removal by particle and oxidation and dry deposition of gas-phase or searching by precipitation. Mercury has the atmospheric residence time from months to a year [56].

\section{Chromium (Cr)}

\section{Nature of chromium}

Chromium $(\mathrm{Cr})$ is the $d$-block transition element in the first row of the VIB group in the periodic table. Its atomic number is 24 , and atomic mass is 52 . Chromium has the density of $7.19 \mathrm{~g} \mathrm{~cm}^{-3}$, the boiling point is $2665^{\circ} \mathrm{C}$ and $1875^{\circ} \mathrm{C}$ is the melting point. Chromium do not occur naturally in the elemental form because it is a less common element but is found in compound form. It is obtained as primary ore by mining and found in $\mathrm{FeCr}_{2} \mathrm{O}_{4}$ or mineral chromite form [52]. Chromium is a nonessential element in the plant's nutrition. Both the $\mathrm{Cr}$ (III) and Cr (VI) forms can be uptaken by the plants. Chromium VI is actively taken up by the plants while Cr III uptake is passive in nature. Chromium can exhibit two different oxidation states $\mathrm{Cr}^{+3}$ and $\mathrm{Cr}^{+6}$. The $\mathrm{Cr}^{+6}$ is known to be more toxic than the $\mathrm{Cr}^{+3}$ form, and $\mathrm{Cr}^{+6}$ can be converted into $\mathrm{Cr}^{+3}$ by redox reactions [19].

\section{Sources of $\mathbf{C r}$}

Some major sources of $\mathrm{Cr}$ contamination comprise of disposal of $\mathrm{Cr}$ contaminated waste and electroplating. Chromium is extensively used in industries as alloying, textile dyes, plating, minimization of water corrosion, animal hides tanning, pressure-treated lumber, refractory bricks, ceramic glazers, and pigments [52].

\section{Effects of $\mathrm{Cr}$ on rice crop}

In plants, particularly rice, chromium at very low concentrations $\left(0.06-1.0 \mathrm{mg} \mathrm{L}^{-1}\right)$ was found to support plant growth and enhance yield, but this is not categorized essential for the plants.

Chromium is the heavy metal which affects the germination process and root growth of plants. An experiment of $\mathrm{Cr}$ VI exhibited that $5 \mathrm{mgL}^{-1}$ dose raised the growth of root comparatively to 
control, and a dose inhibition effect was observed when a higher concentration range of 20-40 $\mathrm{mg} \mathrm{L}^{-1}$ was applied. On the other hand, $\mathrm{Cr}$ III decreased the growth of rice in the concentration of $200 \mathrm{mg} \mathrm{L}^{-1}$. The yield of the plant depends on leaf area, number, and growth. Chromium affects mostly the physiological and biochemical processes in pants, while yield and productivity are also affected. Chromium VI in the irrigation water considerably decreased the yield $\left(\mathrm{Kg} \mathrm{ha}^{-1}\right)$ and weight of grain in paddy rice up-to eighty percent under $200 \mathrm{mgL}^{-1}$ of $\mathrm{Cr}$ [57].

\section{Uptake and translocation mechanism of $\mathbf{C r}$}

There is not a specific mechanism for $\mathrm{Cr}$ uptake by plants. Its uptake occurs by the movement of water and essential nutrients. Cr uptake and translocation by various parts of the plants were different concerning genus or species. In paddy varieties, accumulation of $\mathrm{Cr}$ is different in roots and shoots as with higher concentration in roots and lower in shoots. Amongst $\mathrm{Cr}$ treatments, a greater $\mathrm{Cr}$ content of the paddy was examined in $200 \mathrm{mgl}^{-1}$ of $\mathrm{Cr}$ concentrations while comparing with the other treatments. The shoots accumulated less $\mathrm{Cr}$ than the roots accumulated in all treatments. It can be due to the reason that roots have high cation exchange rate which can significantly reduce the heavy metal movement towards leaves, the limited mobility and availability of heavy metal(oid)s in the root system is the one reason for the greater amount of metal(oid)s in the root system, mostly absorbed $\mathrm{Cr}$ was contained in the vacuoles of roots especially in soluble form and the reason would be immobilization of $\mathrm{Cr}$ in root cell vacuoles, thus rendering this fewer contaminated, which can be a natural response to the toxicity by the plant [58].

Remediation potential of different heavy metal(oid)s

\section{Remediation potential of As}

Fertilizer amendment plays a significant role in the minimization of As toxicity and better crop production. There are various positive reports on the effects of Se and $\mathrm{Si}$ on As accumulation. Both $\mathrm{Si}$ and $\mathrm{As}$ work as the metabolic antipodes; therefore, Si plays an effective role in the reduction of As toxicity.
The latest report depicts that the higher level of As in the soil minimizes $\mathrm{Zn}$ and Se level in rice plants. Silicon-based fertilizers may successfully lower the As accumulation in the rice plant, especially in the As affected soil [6]. Arsenic solubility, release, and retention being significantly impacted by iron oxide minerals. Nitrogen-based fertilizers also have a constructive role in the minimization of As uptake. A pot experiment was held, which revealed that addition of nitrate in rice plants reduces As uptake. Nitrates can stimulate oxidation process of nitrate dependent $\mathrm{Fe}(\mathrm{II})$, leading to adsorption of $\mathrm{Fe}$ (III) in soil by As coprecipitation and can stop the reduction of $\mathrm{Fe}(\mathrm{III})$ [36]. Rice grains contaminated with As are the main source of As in the human beings. Especially those people are effected, which consume a significant quantity of rice and other rice-based products. Therefore, development of highly developed techniques concerned with the in-situ measurements of As compounds, associated genes and elements at subcellular and cellular level is the need of the hour to produce As free rice to eat and stay safe [59].

\section{Remediation potential of $\mathbf{C d}$}

Zheng et al. [42] experimented on the biochar that are produced from various parts of the rice plants (bran, husk, and straw) to examine how biochar may affect the mobility of $\mathrm{Cd}, \mathrm{Pb}, \mathrm{As}$ and $\mathrm{Zn}$ in rice (Oryza sativa L.) seedlings. Concentrations of rice shoot of $\mathrm{Cd} \mathrm{Pb}$ and $\mathrm{Zn}$ lowered by up to $97 \%, 82 \%$, and $73 \%$, respectively, because of biochar amendment, although As enhanced by up to $326 \%$. Biochar amendments considerably lowered the $\mathrm{Cpw}$ (Concentration of pore water) of $\mathrm{Zn}$ and $\mathrm{Cd}$ and enhanced for As. This experiment is the first one to inspect the changes in mobility of metal and formation of iron plaque in rice crop due to amending the previously polluted soil with biochar which shows that biochar has a potential to reduce $\mathrm{Cd}, \mathrm{Pb}$ and $\mathrm{Zn}$ accumulations in the rice shoot but raise the level of As. The main reason is that biochar decreases the $\mathrm{Cpw}$ value of $\mathrm{Cd}$ and $\mathrm{Zn}$ and increase the $\mathrm{Cpw}$ value of As and biochar also increase the $\mathrm{Cd}$ and $\mathrm{Pb}$ blocking capacity of iron plaque. 


\section{Remediation potential of $\mathbf{P b}$}

Scientists have already devised several approaches to combat $\mathrm{Pb}$ and other heavy metal(oid)s. Lead content in the soil can be remediated through biochar amendments. Biochar is a carbon-rich compound which is the product of a bio-waste synthesized through pyrolysis (limited oxygen conditions) having a potential to improve the $\mathrm{Pb}$ contaminated agricultural soil [60]. Biochar application has the potential to immobilize the $\mathrm{Pb}$ concentration in paddy soil and hindered in its accumulation in rice crop [61]. Biochar has active functional groups, porosity, high $\mathrm{pH}$, and high cation exchange capacity, which help $\mathrm{Pb}$ to absorb and then translocate to the other parts of the plants [62].

\section{Remediation potential of $\mathrm{Cu}$}

Exogenous application of different oxides of nitrogen by up-regulating the compounds of some antioxidant defense system such as peroxidase, ascorbate peroxidase, superoxide dismutase and catalase activities and by stimulating P5CS enzyme (D1 pyrroline-5carboxylate synthetase enzyme), that catalase the biosynthesis of proline, has proved that it can resist the impacts caused by $\mathrm{Cu}$ toxicity. Accumulation of $\mathrm{Cu}$ inside the cell can be prevented by the addition of $\mathrm{Mg}^{+2}$ and $\mathrm{Ca}^{+2}$ cations after stimulating the site-specific antagonism for metal ions. Cu toxicity can also be prevented by applying silicon by balancing nutrients and stopping the apoplast bypass stream. Copper contaminated soil can be remediated successfully by applying organic amendments and the use of soil inoculants, i.e. mychorrhizal and arbuscular fungi [25].

\section{Remediation potential of $\mathrm{Al}$}

Many plants have evolved different mechanisms which allow them to bear acid soils and Al toxicity better than other plants. Several ways are present that could restrict aluminum from accumulating in symplastic and apoplastic part of root tissue. Chemistry of cell wall could affect the binding of $\mathrm{Al}$ and the upholding of little higher $\mathrm{pH}$ of rhizosphere that could change the hydrolysis of $\mathrm{Al}^{+3}$ to $\mathrm{Al}(\mathrm{OH})^{+2}$, and this can minimize the deposition in the cell wall, Pectin, the charged residue, will accumulate cations by attracting them, but this content does not constantly correlate with $\mathrm{Al}$ resistance and sensitivity [51].

\section{Remediation potential of $\mathbf{H g}$}

There are not even single species which is $\mathrm{Hg}$ hyper accumulator. Therefore, the natural process of phtyoextraction of $\mathrm{Hg}$ from contaminated soil is limited. The immobilization is an in-situ technique which minimizes the solubility, mobility, and possible toxicity of $\mathrm{Hg}$ by the addition of stabilizing agents into the contaminated soil or water. The agents which are used to immobilize are classified into reducing agents, sulfurcontaining ligands, and absorbing agents. Mercury (II) is the weak Lewis acid and form complexes with the weak Lewis bases, e.g. reduced-S-ligands [63]. Ruiz and Daniell [64] recommended that the new technologies for $\mathrm{Hg}$ phytoremediation depend on diverse gene combinations to increase uptake, chelation, detoxification translocation, and manipulation of plant-mediated discharge of $\mathrm{Hg}$ in the atmosphere.

\section{Remediation potential of $\mathrm{Cr}$}

It is possible to reduce $\mathrm{Cr}$ VI to $\mathrm{Cr}$ III under acidic environment and due to higher redox value of $\mathrm{Cr}$; $\mathrm{Cr}$ III under alkaline conditions can be oxidized to Cr VI. Investigation of potential reduction of $\mathrm{Cr}$ VI and oxidation of $\mathrm{Cr}$ III can be done by using atomic adsorption spectrometer, which measures the filtrate's total $\mathrm{Cr}$ concentration. There are four different mechanisms which explain the sorption of $\mathrm{Cr}$ VI by biosorbents. These four mechanisms include anionic and cationic adsorption, anionic adsorption, reduction, and cationic adsorption, and adsorption coupled reduction [65]. Table 6 gives a comparative analysis of different remediation techniques, their mechanism, applicability, and acceptance. 
Table 5. Comparative summary of heavy metal stress rice plants either in pot or field experiments

\begin{tabular}{|c|c|c|c|c|c|}
\hline Sr. No & Metal(oid)s & Type of experiment & Description of Study & Results & References \\
\hline 1 & $\mathrm{Cd}$ & Pot Experiment & $\begin{array}{l}\text { Effect of Sulfur supply on } \\
\text { accumulation of Cd in brown rice }\end{array}$ & $\begin{array}{l}\text { Excessive } S=\text { reduction of } \mathrm{Cd} \text { but also } \\
\text { reduce the yield of crop }\end{array}$ & [104] \\
\hline 2 & $\mathrm{Cd}, \mathrm{Pb}$ and $\mathrm{As}$ & Pot Experiment & $\begin{array}{l}\mathrm{Cd}, \mathrm{Pb} \text { and } \mathrm{As} \text { pollution and uptake } \\
\text { by rice grown in greenhouse }\end{array}$ & $\begin{array}{c}\text { Distributions of HMs Root }>\text { shoot }> \\
\text { husk }>\text { whole grain. } \\
\text { Accumulation as: } 11.2-43.5 \% \text { of } \\
\mathrm{Cd}, 30.1-88.1 \% \text { of Asand } 14-33.9 \% \text { of } \\
\mathrm{Pb}\end{array}$ & [21] \\
\hline 3 & $\begin{array}{l}\mathrm{Cd}, \mathrm{Cr}, \mathrm{Cu}, \mathrm{Pb}, \mathrm{Zn} \text {, } \\
\mathrm{As}, \mathrm{Mn} \text {, and } \mathrm{Hg}\end{array}$ & Field Experiment & $\begin{array}{l}\text { accumulation and translocation of } \\
\text { heavy metal(oid)s in soil and in } \\
\text { paddy crop irrigated with lake water }\end{array}$ & $\begin{array}{l}\text { Rice roots were enriched in } \mathrm{Cd} \text {, As and } \\
\qquad \mathrm{Pb}\end{array}$ & [75] \\
\hline 4 & As & Field experiment & As Accumulation in Rice Grains & $\begin{array}{l}\text { As conc. depend on soil As level, water } \\
\text { management and cultivars }\end{array}$ & [3] \\
\hline 5 & $\mathrm{~Pb}, \mathrm{Cd}$ & Field Experiment & $\begin{array}{l}\text { Study of correlation between mixed } \\
\text { toxic elements and micronutrients } \\
\text { and their effect on grain yield }\end{array}$ & $\begin{array}{l}\text { Toxic elements and micronutrient } \\
\text { elements show useful variations. Low } \\
\mathrm{Pb} \text { and } \mathrm{Cd} \text { with high micronutrients } \\
\text { produce high grain yield. }\end{array}$ & [105] \\
\hline 6 & $\begin{array}{l}\mathrm{Cd} \mathrm{Zn}, \mathrm{Cu}, \mathrm{Mn} \text { and } \\
\mathrm{Pb}\end{array}$ & Field experiment & $\begin{array}{l}\text { Assessment of heavy metal(oid)s } \\
(\mathrm{Cd} \text { and } \mathrm{Pb}) \text { and micronutrients }\end{array}$ & $\begin{array}{l}\text { Elemental conc. in soil and water was } \\
\text { as } \mathrm{Cd}>\mathrm{Mn}>\mathrm{Zn}>\mathrm{Cu}>\mathrm{Pb}\end{array}$ & [106] \\
\hline 7 & $\mathrm{Hg}$ & Pot Experiment & $\begin{array}{c}\text { Identification soil } \mathrm{Hg} \text { limit and } \mathrm{Hg} \\
\text { accumulation in rice grain }\end{array}$ & $\begin{array}{l}\mathrm{Hg} \text { accumulation is high from seven } \\
\text { different soil samples to rice grain }\end{array}$ & [107] \\
\hline 8 & $\mathrm{Cd}$ and As & Field experiment & $\begin{array}{c}\text { Finding the water management } \\
\text { system to lower the accumulation of } \\
\text { HM }\end{array}$ & $\begin{array}{l}\text { Conventional irrigation ensure high } \\
\text { yield with low As and Cd uptake. }\end{array}$ & [67] \\
\hline 9 & $\mathrm{Cu}, \mathrm{Pb}, \mathrm{Zn}$ and $\mathrm{Cd}$, & Field experiment & $\begin{array}{l}\text { Two combined amendments (HZ \& } \\
\text { LS) were applied at different ratios to } \\
\text { check the bioavailability of HM }\end{array}$ & $\begin{array}{c}\text { Lime stone+ Sepiolite reduced } \\
\mathrm{Pb} 10.6-31.8 \%, \mathrm{Cd} 16.7-25.5 \% \\
\mathrm{Cu} 11.5-22.1 \% \\
\text { Hydroxyhistidine+zeolite reduced } \\
\mathrm{Pb} 5.1-40.8 \%, \mathrm{Cd} 16.7-20.0 \% \\
\mathrm{Cu} 8.1-16.2 \%\end{array}$ & [108] \\
\hline 10 & As & Field experiment & $\begin{array}{c}\text { Study of As accumulation in rice } \\
\text { grain if already present in soil and } \\
\text { effect of iron oxide amendment on As } \\
\text { uptake }\end{array}$ & $\begin{array}{c}\text { High soil As=High As in grain, } \\
\text { Application of iron oxide reduced As } \\
\text { in soil }\end{array}$ & [109] \\
\hline 11 & $\mathrm{Cd}, \mathrm{Cu}$ and $\mathrm{Pb}$ & Field experiment & $\begin{array}{c}\text { Role of iron plaque in mediating } \\
\text { entrance of HM into food chain by } \\
\text { roots of rice }\end{array}$ & $\begin{array}{l}\text { Iron plaques could prevent } \mathrm{Cd} \text { and } \mathrm{Cu} \\
\text { accumulation in rice root, but could } \\
\text { promote } \mathrm{Pb} \text { accumulation therein }\end{array}$ & [15] \\
\hline
\end{tabular}


Javaid et al.

\begin{tabular}{|c|c|c|c|c|}
\hline 12 & $\mathrm{Cd}, \mathrm{Zn}$ and $\mathrm{Pb}$ & Field Experiment & $\begin{array}{c}\text { Effect of bioorganic amendments like } \\
\text { steel slag and limestone on grain } \\
\text { yield and nutrient accumulation in } \\
\text { brown rice }\end{array}$ & $\begin{array}{c}\text { Application of Steel slag decreased the } \\
\text { bioavailability of } \mathrm{Zn}, \mathrm{Pb} \text { and } \mathrm{Cd} \text { by } \\
38.5-91.2 \%\end{array}$ \\
\hline 13 & $\begin{array}{c}\mathrm{Pb}, \mathrm{Ni}, \mathrm{Cr}, \mathrm{As}, \mathrm{Cd}, \\
\mathrm{Cu} \text { and } \mathrm{Zn}\end{array}$ & Field experiment & $\begin{array}{c}\text { Effects of dietary intake of } \mathrm{HMs} \\
\text { through rice in } \mathrm{Cu} \text { mining areas and } \\
\text { assessment of human health }\end{array}$ & $\begin{array}{c}\text { There were strong association between } \\
\text { soil and heavy metal(oid)s }\end{array}$ \\
\hline 14 & $\mathrm{Cd}$ and $\mathrm{Zn}$ & Field experiment & $\begin{array}{c}\text { Uptake and accumulation of } \mathrm{Cd} \text { in } \\
\text { rice and influence of organic } \\
\text { amendments on it. }\end{array}$ & $\begin{array}{c}\text { The treatment with amendments } \\
\text { decreased soil Cd concentration by } 1.6 \\
\text { and 3.3-fold }\end{array}$ \\
\hline 15 & $\mathrm{Cd}, \mathrm{As}$ and $\mathrm{Pb}$ & Field Experiment & $\begin{array}{c}\text { HM accumulation in rice grain } \\
\text { [112] }\end{array}$ & $\begin{array}{c}\text { There were trace amount of } \mathrm{Cd}, \text { As } \\
\text { and Pb in Senegal }\end{array}$ \\
\hline 16 & $\mathrm{Cd}$ and $\mathrm{Pb}$ & Pot Experiment & $\begin{array}{c}\text { Soil amendments: Peanut shell } \\
\text { biochar\& wheat straw biochar used to } \\
\text { enhance the immobilization of } \mathrm{HM}\end{array}$ & $\begin{array}{c}40.4-45.7 \% \text { reduction of Cd and 68.6- } \\
79.0 \%, \text { decrease in } \mathrm{Pb}\end{array}$ \\
\hline
\end{tabular}

Table 6. Comparative analysis of various soil remediation techniques

\begin{tabular}{|c|c|c|c|c|c|c|}
\hline $\begin{array}{c}\text { Remediatio } \\
\text { n Process }\end{array}$ & Techniques & Mechanism & Acceptance & Applicability & $\begin{array}{l}\text { Multi Meal(oids) } \\
\text { Sites }\end{array}$ & $\begin{array}{l}\text { Required Time } \\
\text { Period }\end{array}$ \\
\hline \multirow{4}{*}{$\begin{array}{c}\text { Physical } \\
\text { Remediation }\end{array}$} & Soil Isolation & $\begin{array}{l}\text { Separating the contaminated } \\
\text { soil from uncontaminated } \\
\text { soil by using the sub-surface barriers }\end{array}$ & $\begin{array}{l}\text { Very low and restricted } \\
\text { to the highly } \\
\text { contaminated soils }\end{array}$ & $\begin{array}{l}\text { Small scale } \\
\text { (short to } \\
\text { long term) }\end{array}$ & Effective & Very less \\
\hline & $\begin{array}{c}\text { Soil } \\
\text { Replacement }\end{array}$ & $\begin{array}{l}\text { Digging out the contaminated soil } \\
\text { and then replacing by } \\
\text { clean and fertile soil }\end{array}$ & $\begin{array}{l}\text { Very low and limited } \\
\text { to the highly } \\
\text { contaminated soils }\end{array}$ & $\begin{array}{l}\text { Small scale } \\
\text { ( long term) }\end{array}$ & Effective & Very less \\
\hline & $\begin{array}{l}\text { Electrokinetic } \\
\text { Remediation }\end{array}$ & $\begin{array}{c}\text { Elimination of heavy metal(oids) from } \\
\text { soil by electro-migration or } \\
\text { electrophoresis through DC voltage } \\
\text { application. }\end{array}$ & Very less & $\begin{array}{l}\text { Small scale } \\
\text { (long term) }\end{array}$ & Effective & Very less \\
\hline & Vitrification & $\begin{array}{c}\text { Decline in bioavailability of metal(oids) } \\
\text { by producing vitreous substance using } \\
\text { higher temperature }\end{array}$ & Very less & $\begin{array}{l}\text { Small scale } \\
\text { (long term) }\end{array}$ & Effective & Very less \\
\hline \multirow[t]{2}{*}{$\begin{array}{c}\text { Biological } \\
\text { Remediation }\end{array}$} & $\begin{array}{l}\text { Phyto- } \\
\text { Extraction }\end{array}$ & $\begin{array}{l}\text { Usage of hyperaccumulators to uptake, } \\
\text { concentrate and translocate heavy } \\
\text { Metal(oids) from the soil to parts of } \\
\text { harvestable plant. }\end{array}$ & $\begin{array}{l}\text { The highest } \\
\text { public } \\
\text { acceptability }\end{array}$ & $\begin{array}{l}\text { Large scale } \\
\text { (long term) }\end{array}$ & $\begin{array}{l}\text { Usually very } \\
\text { less except for a } \\
\text { few plants }\end{array}$ & Very high \\
\hline & $\begin{array}{l}\text { Microbial } \\
\text { Assisted }\end{array}$ & $\begin{array}{l}\text { Use of microorganisms to improve plant } \\
\text { capacity of phytoextraction. }\end{array}$ & $\begin{array}{l}\text { The highest public } \\
\text { acceptability }\end{array}$ & $\begin{array}{l}\text { Large scale } \\
\text { (long term) }\end{array}$ & $\begin{array}{l}\text { Normally very } \\
\text { less but more }\end{array}$ & $\begin{array}{l}\text { Very high but } \\
\text { also a lesser }\end{array}$ \\
\hline
\end{tabular}




\begin{tabular}{|c|c|c|c|c|c|c|}
\hline & $\begin{array}{c}\text { Phyto- } \\
\text { Extraction }\end{array}$ & & & & $\begin{array}{c}\text { efficient than } \\
\text { phytoextraction }\end{array}$ & $\begin{array}{c}\text { amount than } \\
\text { phytoextraction } \\
\text { alone }\end{array}$ \\
\hline & $\begin{array}{l}\text { Chelated } \\
\text { Assisted Phyto- } \\
\text { Extraction }\end{array}$ & $\begin{array}{l}\text { Use of inorganic and organic ligands to } \\
\text { increase phytoextraction capability of } \\
\text { plants }\end{array}$ & $\begin{array}{l}\text { Higher public } \\
\text { acceptability }\end{array}$ & $\begin{array}{l}\text { Small to } \\
\text { medium scale } \\
\text { (long-term) }\end{array}$ & $\begin{array}{l}\text { Generally Low: } \\
\text { Effective than } \\
\text { Phytoextraction }\end{array}$ & $\begin{array}{l}\text { Very high but } \\
\text { require less than } \\
\text { phytoextraction }\end{array}$ \\
\hline & $\begin{array}{c}\text { Phyto- } \\
\text { Stabilization }\end{array}$ & $\begin{array}{l}\text { Usage of plants to reduce metal mobility } \\
\text { and bioavailability in soils through } \\
\text { sequestration in the roots of plant. }\end{array}$ & $\begin{array}{l}\text { Medium } \\
\text { public } \\
\text { acceptability }\end{array}$ & $\begin{array}{l}\text { Small to } \\
\text { medium scale } \\
\text { (short-term) }\end{array}$ & Very low & Very high \\
\hline & $\begin{array}{c}\text { Phyto- } \\
\text { Volatilization }\end{array}$ & $\begin{array}{l}\text { Plant uptake of heavy metal(oids) from } \\
\text { soil and excrete into the atmosphere in } \\
\text { vapors form. }\end{array}$ & $\begin{array}{l}\text { Less to medium public } \\
\text { acceptability }\end{array}$ & $\begin{array}{l}\text { Small to } \\
\text { medium scale } \\
\text { (long-term) }\end{array}$ & No & Very High \\
\hline \multirow{2}{*}{$\begin{array}{c}\text { Chemical } \\
\text { Remediation }\end{array}$} & Soil Washing & $\begin{array}{l}\text { Elimination of heavy metals from soil by } \\
\text { using extractants and } \\
\text { Forming mobile and stable complexes }\end{array}$ & $\begin{array}{l}\text { Medium to } \\
\text { high public } \\
\text { acceptability }\end{array}$ & $\begin{array}{l}\text { Small scale } \\
\text { (long term) }\end{array}$ & $\begin{array}{l}\text { Effective. } \\
\text { But depends upon } \\
\text { the type of, } \\
\text { metal(oids), } \\
\text { mobilizing } \\
\text { Amendment and } \\
\text { soil }\end{array}$ & $\begin{array}{l}\text { A smaller } \\
\text { amount to } \\
\text { medium }\end{array}$ \\
\hline & Immobilization & $\begin{array}{c}\text { Decrease in metal } \\
\text { bioavailability and mobility by } \\
\text { using immobilizing } \\
\text { amendments, and making immobile and } \\
\text { stable complexes through adsorption }\end{array}$ & $\begin{array}{l}\text { Higher public } \\
\text { acceptability }\end{array}$ & $\begin{array}{l}\text { Small to } \\
\text { medium scale } \\
\text { (short-term) }\end{array}$ & $\begin{array}{c}\text { Effective. } \\
\text { But depends upon } \\
\text { the type of, } \\
\text { metal(oids), } \\
\text { mobilizing } \\
\text { Amendment and } \\
\text { soil. }\end{array}$ & $\begin{array}{l}\text { Fewer to } \\
\text { medium }\end{array}$ \\
\hline
\end{tabular}




\section{Conclusions and future prospects}

Natural or biogeochemical processes, anthropogenic sources such as hazardous solid waste and industrial wastewater are the major causes of heavy metal accumulation in the soil, which ultimately deteriorate the quality of life by disturbing food chain. Elevated levels of heavy metal(oid)s ( $\mathrm{Al}, \mathrm{As}, \mathrm{Cd}, \mathrm{Cu}$, $\mathrm{Cr}$, and $\mathrm{Hg}$ ) in soil have toxic effects on animals, plants, humans, and other living beings. Heavy metal accumulation and their toxicity in agricultural soil and water can be eliminated through hyper accumulator plants by using phytoremediation or bioremediation process. To ensure the consistent parameters for health risk assessment, it is essential to identify the heavy metal bioavailability in different areas, soil, and crops. The collection of precise information on the evolutionary change of heavy metals in soils and plants is crucial, and further studies are required to determine the input of bioavailable metals to enhancing soil quality to attain food security and sustainable agriculture. Thus, there is the need to deepen the research work for better understanding of the toxicity of heavy metal(oid)s on rice or other plants and its allied areas to establish ecological equilibrium on earth.

\section{Authors' contributions}

Idea about manuscript: Q Zaman \& K Sultan, Collected the data: S Javaid \& S Sharif, Prepared the manuscript: S Javaid \& S Sharif, Prepared the tables and figures: S Aslam, A Jamil \& S Ibraheem, Technically improved the draft: U Riaz, A Aslam \& N Ehsan.

\section{References}

1. FAOSTAT (2018). Food and Agriculture Organization of the United Nations Statistics Division. Retrieved from http://faostat3.fao.org/

2. FAOSTAT (2017). Food and Agriculture Organization of the United Nations Statistics Division. Retrieved from http://faostat3.fao.org/

3. Hua B, Yan W, Wang J, Deng B \& Yang J (2011). Arsenic Accumulation in Rice
Grains: Effects of Cultivars and Water Management Practices. Environ Eng Sci 28: 591-596.

4. Ashraf U, Adam SK, Zhaowen M, Saddam H, Shakeel AA, Imran K, Rana NA \& Xiangru $T$ (2015). Lead toxicity in rice: effects, mechanisms, and mitigation strategies-a mini review. Environ Sci Pollut Res 22: 18318-18332.

5. Seck PA, Diagne A, Mohanty S \& Wopereis MC (2012). Crops that feed the world 7: Rice Food Secu 4(1):7-24.

6. Zhuang P, Zhang C, Li Y, Zou B, Mo H, Wu K, Wu J \& Li Z (2016). Assessment of influences of cooking on cadmium and arsenic bio accessibility in rice, using an in vitro physiologically-based extraction test. Food Chem 213: 206-214.

7. Godfray J, Charles H, Beddington JR, Crute IR, Hadded L, Lawrence D, Muir JF, Pretty J, Robinson S, Thomas SM \& Toulmin C (2010). Food Security: The Challenge of Feeding 9 Billion People. Sci 327(5967): 812-818.

8. FAOSTAT (2014). Food and Agriculture Organization of the United Nations Statistics Division. Retrieved from http://faostat3.fao.org/

9. Civa'n ${ }^{`} \mathrm{P}$, Craig H, Cox CJ \& Brown TA (2015). Three geographically separate domestications of Asian rice. Nat Plants 1: 15164

10. Shoaib AW, Luan J, Xiao S, Sanaullah N, Irfana NM, Qurat UAM \& Ghulam HW (2016). Economic Assessment of Rice Production in Sindh, Pakistan. AJERE 1(1): 37-42.

11. Govt. of Pakistan (2017). Economic Survey of Pakistan 2016-17. Finance Division, Islamabad.

12. Govt. of Punjab (2017). Kharif Crops Final Estimates Data Book 2016-17. Directorate of Agriculture, Crop Reporting Service, Punjab.

13. Muhammad AMS \& Rizwan M (2014). Basmati- 515: a new variety with extralong grain for productivity augmentation in Punjab, Pak J Agric Res 52(1). 
14. Nirmala B \& Muthuraman P (2009). Economic and Constraint Analysis of Rice Cultivation in Kaithal District of Haryana. IRJEE 9(1): 47-49.

15. Zhou H, Zeng M, Zhou X, Liao B, Peng P, Hu M, Zhu W, Wu Y \& Zou Z (2015). Heavy metal translocation and accumulation in iron plaques and plant tissues for 32 hybrid rice (Oryza sativa L.) cultivars. Plant Soil 386: 317-329.

16. Wintz H, Fox T \& Vulpe C (2002). Responses of plants to iron, zinc and copper deficiencies. Biochem Soc Trans 30: 766-768.

17. Reeves RD \& Baker AJM (2000). Metalaccumulating plants. In: Raskin I, Ensley BD (eds) Phytoremediation of toxic metals: using plants to clean up the environment. Wiley, New York. 193-229.

18. Monni S, Salemma M \& Millar N (2000). The tolerance of Empetrum nigrum to copper and nickel. Int J Environ Pollut 109: 221-229.

19. Nagajyoti PC, Lee KD \& Sreekanth TVM (2010). Heavy metals, occurrence and toxicity for plants: a review. Environ Chem Lett 8(3): 199-216.

20. Riaz U, Murtaza G, Saifullah \& Farooq M (2018). Influence of different sewage sludges and composts on growth, yield, and trace elements accumulation in rice and wheat. Land Degrad Dev 29(5): 1343-1352.

21. Lei M, Tie B, Williams PN, Zheng Y \& Huang Y (2011). Arsenic, cadmium, and lead pollution and uptake by rice (Oryza sativa L.) grown in greenhouse. J Soil Sediment 11: 115-123.

22. Zeng F, Wei W, Li M, Huang R, Yang F $\&$ Duan Y (2015). Heavy Metal Contamination in Rice-Producing Soils of Hunan Province, China and Potential Health Risks. Int $J$ Environ Res Public Health 12: 15584-15593.

23. Dubey RS (2011). Metal toxicity, oxidative stress and antioxidative defense system in plants. Reactive Oxygen Species and Antioxidants in Higher
Plants, S. D. Gupta, Ed., 177-203. CRC Press, Boca Raton, FL, USA,

24. Wang X, Hua L \& Ma Y (2012). A biotic ligand model predicting acute copper toxicity for barley (Hordeum vulgare): Influence of calcium, magnesium, sodium, potassium and $\mathrm{pH}$. Chemosphere 89: 89-95.

25. Arunakumara KKIU, Walpola BC \& Yoon M (2013). Current status of heavy metal contamination in Asia's rice lands. Rev Environ Sci Biotechnol 12: 355-377.

26. Zhao FJ, McGrath SP \& Meharg AA (2010). Arsenic as a food chain contaminant: mechanisms of plant uptake and metabolism and mitigation strategies, Annu Rev Plant Biol 61: 535-559.

27. Xue S, Shi L, Wu C, Wu H, Qin Y, Pan W, Hartley W \& Cui M (2017). Cadmium, lead, and arsenic contamination in paddy soils of a mining area and their exposure effects on human HEPG2 and keratinocyte cell-lines. Environ Res 156 : 23-30.

28. Shahid M, Pourrut B, Dumat C, Nadeem M, Aslam M, Pinelli E (2014). Heavymetal- induced reactive oxygen species: phytotoxicity and physicochemical changes inplants. Rev Environ Contam Toxicol 232: 1-44.

29. Chen WQ, Shi YL, Wu SL \& Zhu YG (2016). Anthropogenic arsenic cycles: a research framework and features. J Clean Prod 139: 328-336.

30. Hayat K, Menhas S, Bundschuh J \& Chaudhary HJ (2017). Microbial biotechnology as an emerging industrial wastewater treatment process for arsenic mitigation: a critical review. J Clean Prod 151: 427-438.

31. Jia Y, Huang H, Sun GX, Zhao FJ \& Zhu YG (2012). Pathways and relative contributions to arsenic volatilization from rice plants and paddy soil. Environ Sci Technol 46: 8090-8096.

32. Shakoor M, Niazi NK, Irshad B, Murtaza G, Kunhikrishnan A, Seshadri B, Shahid M, Ali S, Bolan S, Yong N, Muhammad Abid SO \& Ali F (2016). Remediation of 
arsenic- contaminated water using agricultural wastes as biosorbents. Crit Rev Environ Sci Technol 46: 467-499.

33. Shakoor M, Niazi N, Bibi I, Rahman M, Naidu R, Dong Z, Shahid M \& Arshad M (2015). Unraveling health risk and speciation of arsenic from groundwater in rural areas of Punjab, Pakistan. Int $J$ Environ Res Public Health 12: 1237112390.

34. Waqas H, Shan A, Khan YG, Nawaz R, Rizwan M, Saif-Ur-Rehman M, Shakoor MB, Ahmed W, Jabeen M. (2017). Human health risk assessment of arsenic in groundwater aquifers of Lahore. Pakistan. Hum Ecol Risk Assess 23: 836850.

35. Ullah S, Dahlawi S, Naeem A, Iqbal M, Farooq MA, Bibi S \& Rengel Z. (2018). Opportunities and challenges in the use of mineral nutrition for minimizing arsenic toxicity and accumulation in rice: A critical review. Chemosphere 194:171188.

36. Bakhat HF, Zia Z, Fahad S, Abbas S, Hammad HM, Shshzad AN, Abbas F, Alharby H \& Shahid M (2017). Arsenic uptake, accumulation and toxicity in rice plants: Possible remedies for its detoxification: A review. Environ Sci Pollut Res Int 24(10): 9142-9158.

37. Shakoor MB, Nawaz R, Hussain F, Raza M, Ali S, Rizwan M, Oh SE \& Ahmad S (2017). Human health implications, risk assessment and remediation of Ascontaminated water: a critical review. Sci Total Environ 601: 756-769

38. Niazi NK, Murtaza B, Bibi I, Shahid M, White JC, Nawaz MF, Bashir S \& Murtaza G (2016). Removal and recovery of metals by biosorbents and biochars derived from biowastes. Environmental Materials and Waste: Resource Recovery and Pollution Prevention.

39. Arao T, Ishikawa S, Murakami M, Abe K, Maejima Y \& Makino T (2010). Heavy metal contamination of agricultural soil and countermeasures in Japan. Paddy Water Environ 8 (3): 247-257.
40. Kao CH (2017). Cadmium Stress in Rice: Transporters Involved in Cadmium Accumulation. Crop Environ Bioinform 14: 1-4.

41. Ahmad I, Akhtar MJ, Zahir ZA \& Jamil A (2012). "Effect of cadmium on seed germination and seedling growth of four wheats (Triticum aestivum L.) cultivars," Pak J Bot 44(5): 1569-1574.

42. Zheng RL, Cai C, Liang JH, Huang Q, Cheng Z, Huang YZ, Arp HPH \& Sun GX. (2012). The effects of biochars from rice residue on the formation of iron plaque and the accumulation of $\mathrm{Cd}, \mathrm{Zn}$, $\mathrm{Pb}$, As in rice (Oryza sativa $\mathrm{L}$.) seedlings. Chemosphere 89: 856-862.

43. Uzu G, Sobanska S, Aliouane Y, Pradere P \& Dumat C (2009). Study of lead phytoavailability for atmospheric industrial micronic and sub-micronic particles in relation with lead speciation. Environ Pollut 157(4): 1178-1185.

44. Punamiya P, Datta R, Sarkar D, Barber S, Patel M \& Das P (2010). Symbiotic role of Glomus mosseae in phytoextraction of lead in vetiver grass [Chrysopogon zizanioides (L.)]. J Hazard Mater 177(13): 465-474.

45. Hseu ZY, Su SW, Lai HY, Guo HY, Chen TC \& Chen ZS (2010). Remediation techniques and heavy metal uptake by different rice varieties in metalcontaminated soils of Taiwan: new aspects for food safety regulation and sustainable agriculture. Soil Sci Plant Nutr 56: 31-52.

46. Cheng WD, Zhang GP, Yao HG, Wu W \& Xu M (2006). Genotypic and environmental variation in cadmium, chromium, arsenic, nickel and lead concentrations in rice grains. $J$ Zhejiang Uni Sci B 7: 565-571.

47. Basnet $\mathrm{P}$, Amarasiriwardena D, Wu F, Fu $\mathrm{Z}$ \& Zhang $\mathrm{T}$ (2014). Elemental bioimaging of tissue level trace metal distributions in rice seeds (Oryza sativa L.) from a mining area in China. Environ Pollut 195: 148-156. 
48. Yuan HM, Xu HH, Liu WC \& Lu YT (2013). Copper regulates primary root elongation through PIN1-mediated auxin redistribution. Plant Cell Physiol 54: 766778.

49. $\mathrm{Yu}$ GH, Wu MJ, Wei GR, Luo YH, Ran W, Wang BR, Zhang JC \& Shen QR (2012). Binding of organic ligands with $\mathrm{Al}$ (III) in dissolved organic matter from soil: implications for soil organic carbon storage. Environ Sci technol 46: 61026109.

50. Frankowski M (2016). Aluminium uptake and migration from the soil compartment into Betula pendula for two different environments: a polluted and environmentally protected area of Poland. Environ Sci Pollut Res 23:1398-1407.

51. Horst WJ, Wang YX \& Eticha D (2010). The role of the root apoplast in aluminiuminduced inhibition of root elongation and in aluminium resistance of plants: a review. Ann Bot 106: 185-197.

52. Wuana AR (2011) Heavy Metals in Contaminated Soils: A Review of Sources, Chemistry, Risks and Best Available Strategies for Remediation, ISRN Ecol 20.

53. Pirrone $\mathrm{N}$, Cinnirella $\mathrm{S}$, Feng $\mathrm{X}$, Finkelman RB, Friedli HR, Leaner J, Mason R, Mukherjee AB, Stracher GB, Streets DG \& Telmer K (2010). Global mercury emissions to the atmosphere from anthropogenic and natural sources. Atmos Chem Phys 10 (13): 5951-5964.

54. Wang Q, Kim D, Dionysiou DD, Sorial GA \& Timberlake D (2004). Sources and remediation for mercury contamination in aquatic systems- A literature review. Environ Pollut 131(2): 323-336.

55. Asati A, Pichhode M \& Nikhil K. (2016). Effect of Heavy Metals on Plants: An Overview. Int J Innov Eng Res Mana. 5(3): 56-66.

56. Sprovieri F, Pirrone N, Ebinghaus R, Kock H \& Dommergue A (2010). A review of worldwide atmospheric mercury measurements. Atmos Chem Phys 10: 8245-8265.
57. Sundaramoorthy P, Chidambaram A, Ganesh KS, Unnikannan P \& Baskaran L (2010). Chromium stress in paddy: (i) nutrient status of paddy under chromium stress; (ii) phytoremediation of chromium by aquatic and terrestrial weeds. $\mathrm{CR}$ Biol 333(8): 597-607.

58. Nagarajan M \& Ganesh KS (2015). Toxic effects of chromium on growth of some paddy varieties. Int Lett Nat Sci 35: 36-44.

59. Kumarathilaka P, Seneweera S, Mehrag A \& Bundschuh J (2018). Arsenic accumulation in rice (Oryza sativa L.) is influenced by environment and genetic factors. Sci Total Environ 642: 485-496.

60. Lehmann J (2007). A handful of carbon. Nature 447: 143-144.

61. Bian R, Chen D, Liu X, Cui L, Li L, Pan G, Xie D, Zheng J, Zhang X \& Zheng J (2013). Biochar soil amendment as a solution toprevent Cdtainted rice from China: results from a cross-site field experiment. Ecol Eng 58: 378-383.

62. Zhang X, Wang H, He L, Lu K, Sarmah A, Li J, Bolan NS, Pei J \& Huang $\mathrm{H}$ (2013). Using biochar forremediation of soils contaminated with heavy metals and organic pollutants. Environ Sci Pollut $R$ 20: 8472-8483.

63. Bower J, Savage KS, Weinman B, Barnett MO, Hamilton WP \& Harper WF (2008). Immobilization of mercury by pyrite (FeS2). Environ Pollut 156: 504-514.

64. Ruiz ON \& Daniell H (2009). Genetic engineering to enhance mercury phytoremediation. Curr Opin Chem Biol 20: 213-219.

65. Saha B \& Orvig C (2010). Biosorbents for hexavalent chromium elimination for industrial and municipal effluents. Coord Chem Rev 254: 2959-2972.

66. Hossain $M$, Islam $M$, Jahiruddin $M$, Abedin A, Islam S \& Meharg A (2007). Effects of arsenic- contaminated irrigation water on growth, yield, and nutrient concentration in rice. Commun Soil Sci Plant Anal 39: 302-313.

67. Hu P, Li Z, Yuan C, Ouyang Y, Zhou L, Huang J, Huang Y, Luo Y, Christie P \& 
Wu L (2013) Effect of water management on cadmium and arsenic accumulation by rice (Oryza sativa L.) with different metal accumulation capacities. J Soil Sediment 13: 916-924.

68. Mahmood S, Ishtiaq S, Malik MI \& Ahmed A (2013). Differential growth and photosynthetic responses and pattern of metal accumulation in sunflower (Heliathus annuus L.) cultivars at elevated levels of lead and mercury. Pak J Bot 45: 367-374.

69. Ansari MKA, Oztetik E, Umar S, Iqbal M \& Owens G (2013). Identification of the phytoremediation potential of Indian mustard genotypes for copper, evaluated from a hydroponic experiment. Clean Soil Air Water 41: 789-796.

70. Laspina NV, Groppa MD, Tomaro ML \& Benavides MP (2005). Nitric oxide protects sunflower leaves against $\mathrm{Cd}$ induced oxidative stress. Plant Sci 169: 323-330.

71. Hidayatun N, Diaz MGQ \& Ismail AM (2017). Exploring Aluminum Tolerance at seedling stage in Rice (Oryza sativa Linn) by Using Modified Magnavaca Nutrient Solution. Buletin Plasma Nutfah 23(2): 81-90.

72. Islam LN (2015). Immunotoxic Effects of Arsenic Exposure. In: Handbook of Arsenic Toxicol 493-519.

73. Chen H L, Lee CC, Huang WJ, Huang HT, Wu YC, Hsu YC \& Kao YT (2015). Arsenic speciation in rice and risk assessment of inorganic arsenic in Taiwan population. Environ Sci Pollut R 1-8.

74. Sommella A, Deacon C, Norton G, Pigna M, Violante A \& Meharg AA (2013). Total arsenic, inorganic arsenic, and other elements concentrations in Italian rice grain varies with origin and type. Environ Pollut 18: 38-43.

75. Singh J, Upadhyay SK, Patha RK \& Gupta V (2011). Accumulation of heavy metals in soil and paddy crop (Oryza sativa), irrigated with water of Ramgarh Lake, Gorakhpur, UP, India. Toxicol Environ Chem 93(3): 462-473.
76. Alina M, Azrina A, Muhammad YAS, Muhammad ZS, Muhammad IEH. \& Muhammad RR (2012). Heavy metals (mercury, arsenic, cadmium, plumbum) in selected marine fish and shellfish along the Straits of Malacca. Int Food Res $J$ 19(1): 135-140.

77. Matsumoto ST, Mantovani MS, Malaguttii MIA, Dias AL, Fonseca IC \& Marin-Morales MA (2006). Genotoxicity and mutagenicity of water contaminated with tannery effluents, as evaluated by the micronucleus test and comet assay using the fish Oreochromis niloticus and chromosome aberrations in onion roottips. Genet Mol Biol 29(1): 148-158.

78. Acosta JA, Arocena JM, \& Faz A (2015). Speciation of arsenic in bulk and rhizosphere soils from artisanal cooperative mines in Bolivia. Chemosphere 138: 1014-1020.

79. Myoung Soo Ko MS, Kim JY, Park HS, \& Kim KW (2015). Field assessment of arsenic immobilization in soil amended with iron rich acid mine drainage sludge. J Clean Prod 108: 1073-1080.

80. Wei C, Ge Z, Chu W \& Feng R (2015). Speciation of antimony and arsenic in the soils and plants in an old antimony mine. Environ Exp Bot 109: 31-39.

81. Marabottini R, Stazi SR, Papp R, Grego S, \& Moscatelli MC (2013). Mobility and distribution of arsenic in contaminated mine soils and its effects on the microbial pool. Ecotoxicol Environ Saf 96: 147153.

82. Beesley L, Inneh OS, Norton GJ, MorenoJimenez E, Pardo T, Clemente R \& Dawson JJ (2014). Assessing the influence of compost and biochar amendments on the mobility and toxicity of metals and arsenic in a naturally contaminated mine soil. Environ Pollut 186: 195-202.

83. Shi GL, Zhu S, Bai SN, Xia Y, Lou LQ \& Cai QS (2015). The transportation and accumulation of arsenic, cadmium, and phosphorus in 12 wheat cultivars and their 
relationships with each other. $J$ Hazard Mater 299: 94-102.

84. Torres LG, Lopez RB \& Beltran M (2012). Removal of $\mathrm{As}, \mathrm{Cd}, \mathrm{Cu}, \mathrm{Ni}, \mathrm{Pb}$, and $\mathrm{Zn}$ from a highly contaminated industrial soil using surfactant enhanced soil washing. Phys Chem Earth 37-39: 3036.

85. Quezada-hinojosa R, Föllmi KB, Gillet F, \& Matera V (2015). Cadmium accumulation in six common plant species associated with soils containing high geogenic cadmium concentrations at Le Gurnigel, Swiss Jura Mountains EX. Catena 124: 8596.

86. Tiwari KK, Singh NK, Patel MP, Tiwari MR \& Rai UN (2011). Metal contamination of soil and translocation in vegetables growing under industrial wastewater irrigated agricultural field of Vadodara, Gujarat, India. Ecotoxicol Environ Saf 74: 1670-1677.

87. Baldantoni D, Morra L, Zaccardelli M \& Alfani A (2016). Cadmium accumulation in leaves of leafy vegetables. Ecotoxicol Environ Saf 123: 89-94.

88. Shaheen SM, Rinklebe J, Rupp H \& Meissner R (2014). Temporal dynamics of pore water concentrations of $\mathrm{Cd}, \mathrm{Co}, \mathrm{Cu}$, $\mathrm{Ni}$, and $\mathrm{Zn}$ and their controlling factors in a contaminated floodplain soil assessed by undisturbed groundwater lysimeters. Environ Pollut 191: 223-231.

89. Panagopoulos I, Karayannis A, Kollias K, Xenidis A \& Papassiopi N (2015). Investigation of potential soil contamination with $\mathrm{Cr}$ and $\mathrm{Ni}$ in four metal finishing facilities at Asopos industrial area. J Hazard Mater 281: 2026.

90. Xu X, Zhao Y, Zhao X, Wang Y \& Deng $W$ (2014). Sources of heavy metal pollution in agricultural soils of a rapidly industrializing area in the Yangtze Delta of China. Ecotoxicol Environ Saf 108: 161-167.

91. Arenas-Lago D, Andrade ML, Vega FA \& Singh BR (2016). TOF-SIMS and FESEM/EDS to verify the heavy metal fractionation in serpentinite quarry soils. Catena 136: 30-43.

92. Anjos C, Magalhães MCF \& Abreu MM (2012). Metal (Al, Mn, Pb and Zn) soils extractable reagents for available fraction assessment, comparison using plants, and dry and moist soils from the Braçal abandoned lead mine area, Portugal $J$ Geochem Explor113: 45-55.

93. Wang Q, Liu J \& Cheng S (2015). Heavy metals in apple orchard soils and fruits and their health risks in Liaodong Peninsula, Northeast China. Environ Monit Assess 187 (1): 1-8.

94. Sacristán D, Rossel RAV \& Recatalá L (2016). Proximal sensing of $\mathrm{Cu}$ in soil and lettuce using portable X-ray fluorescence spectrometry. Geoderma 265: 6-11.

95. Avci H \& Deveci T (2013). Assessment of trace element concentrations in soil and plants from cropland irrigated with wastewater. Ecotoxicol Environ Saf 98: 283-291.

96. Mapanda F, Mangwayana EN, Nyamangara J \& Giller KE (2007). Uptake of heavymetals by vegetables irrigated using wastewater and the subsequent risks in Harare, Zimbabwe. Phys Chem Earth 32: 1399-1405.

97. Carvalho DRM, dos Santos JA, Silva JAS, do Prado TG, da Fonseca AF, Chaves ES \& Frescura VLA (2015). Determination of metals in Brazilian soils by inductively coupled plasma mass spectrometry. Environ Monit Assess 187: 535.

98. Nabulo G, Black CR, Craigon J \& Young SD (2012). Does consumption of leafy vegetables grown in peri-urban agriculture pose a risk to human health? Environ Pollut 162: 389-398.

99. Nabulo G, Black CR \& Young SD (2011). Tracemetal uptake by tropical vegetables grown on soil amended with urban sewage sludge. Enviro Pollut 159: 368-376.

100. Niu LQ, Jia P, Li SP, Kuang JL, He XX, Zhou WH \& Li JT (2015). Slash and char, an ancient agricultural technique holds new promise for management of soils 
contaminated by $\mathrm{Cd}, \mathrm{Pb}$ and $\mathrm{Zn}$. Environ Pollut 205: 333-339.

101. Luo S, Lian C, Chen L, Liang J, Xiao X, $\mathrm{Xu} \mathrm{T}$, Ying W, Rao Y, Liu C, Bin C, Liu Y, Tang L, Zeng C \& Ming G (2011). Analysis and characterization of cultivable heavy metal-resistant bacterial endophytes isolated from $\mathrm{Cd}$ hyperaccumulator Solanum nigrum L. and their potential use for phytoremediation. Chemosphere 85: 113-1138.

102. Kwon MS, Yu Y, Coburn C, Phillips AW, Chung K, Shanker A, Jung J, Kim G, Pipe K, Forrest SR, Youk JH, Gierschner J \& Kim J (2015). Suppressing molecular motions for enhanced room-temperature phosphorescence of metal-free organic materials. Nat Commun 6: 8947.

103. Obiora SC, Chukwu A \& Davies TC (2016). Heavy metals and health risk assessment of arable soils and food crops around $\mathrm{Pb}$ e $\mathrm{Zn}$ mining localities in Enyigba, southeastern Nigeria. J African Earth Sci 116: 182-189.

104. Fan JL, Hu ZY, Ziadi N, Xia X \& Wu C (2010). Excessive sulfur supply reduces cadmium accumulation in brown rice (Oryza sativa L.). Environ Pollut 158: 409-415.

105. Li B, Wang X, Qi X, Huang L \& Ye Z (2012). Identification of rice cultivars with low brown rice mixed cadmium and lead contents and their interactions with the micronutrients iron, zinc, nickel and manganese. J Environ Sci 24(10): 17901798.

106. Reddy MV, Satpathy D \& Dhiviya KS (2013). Assessment of heavy metals (Cd and $\mathrm{Pb})$ and micronutrients $(\mathrm{Cu}, \mathrm{Mn}$, and Zn) of paddy (Oryza sativa L.) field surface soil and water in a predominantly paddy-cultivated area at Puducherry (Pondicherry, India), and effects of the agricultural runoff on the elemental concentrations of a receiving rivulet. Environ Monit Assess 185: 6693-6704.
107. Liu C, Wu C, Rafiq MT, Aziz R, Hou D, Ding Z, Lin Z, Lou L, Lou L, Feng Y, Li $T$ \& Yang $X$ (2013). Accumulation of mercury in rice grain and cabbage grown on representative Chinese soils. J Zhejiang. Univ Sci B 14(12): 1144-1151.

108. Zhou H, Zhou X, Zeng M, Liao B, Liu L, Yang W, Wu Y, Qiu Q \& Wang Y (2014). Effects of combined amendments on heavy metal accumulation in rice (Oryza sativa L.) planted on contaminated paddy soil. Ecotox Environ Safe 101: 226-232.

109. Farrow EM, Wang J, Burken JG, Shi H, Yan W, Yang J, Hua B \& Deng B (2015). Reducing arsenic accumulation in rice grain through iron oxide amendment. Ecotox Environ Safe 118: 55-61.

110. He H, Tam NFY, Yao A, Qiu R, Li WC \& Ye Z (2016). Effects of alkaline and bioorganic amendments on cadmium, lead, zinc, and nutrient accumulation in brown rice and grain yield in acidic paddy fields contaminated with a mixture of heavy metals. Environ Sci Pollut Res 23: 23551-23560.

111. Giri S \& Singh AK (2017). Human health risk assessment due to dietary intake of heavy metals through rice in the mining areas of Singhbhum Copper Belt, India. Environ Sci Pollut Res 14945-14956.

112. Saengwilai P, Meeinkuirt W, Pichtel J \& Koedrith P. (2017). Influence of amendments on $\mathrm{Cd}$ and $\mathrm{Zn}$ uptake and accumulation in rice (Oryza sativa L.) in contaminated soil. Environ Sci Pollut Res 24(18): 15756-15767.

113. Ndong M, Mise N, Okunaga M \& Kayama F (2018). Cadmium, arsenic and lead accumulation in rice grains produced in Senegal River valley. Fundam Toxicol Sci 5(2): 87-91.

114. Xu C, Chen HX, Ziang Q, Zhu HH, Wang S, Zhu QH, Huang DY \& Zhang YZ (2018). Effect of peanut shell and wheat straw biochar on the availability of $\mathrm{Cd}$ and $\mathrm{Pb}$ in a soil-rice (Oryza sativa L.) system. Environ Sci Pollut Res 25: 1147-1156. 